\title{
Improving analyses of sanctions busting
}

Article

Accepted Version

Golub, J. (2020) Improving analyses of sanctions busting. Peace Economics, Peace Science and Public Policy, 26 (2). 20190043. ISSN 1554-8597 doi: https://doi.org/10.1515/peps2019-0043 Available at https://centaur.reading.ac.uk/89221/

It is advisable to refer to the publisher's version if you intend to cite from the work. See Guidance on citing.

To link to this article DOI: http://dx.doi.org/10.1515/peps-2019-0043

Publisher: De Gruyter

All outputs in CentAUR are protected by Intellectual Property Rights law, including copyright law. Copyright and IPR is retained by the creators or other copyright holders. Terms and conditions for use of this material are defined in the End User Agreement.

\section{www.reading.ac.uk/centaur}

\section{CentAUR}

Central Archive at the University of Reading

Reading's research outputs online 


\title{
Improving Analyses of Sanctions Busting
}

\author{
Jonathan Golub \\ University of Reading
}

\begin{abstract}
When economic sanctions are directed against a target state by a sender state, the sender obviously wants third countries to participate with the sanctions and can apply pressure on them to prevent sanctions busting behaviour. But why does sanctions busting vary, so that the target's trade with some third-countries increases but with others decreases? In this paper I offer two improvements to the analysis of sanctions busting: a theoretical framework that recognises how the effects of covariates on sanctions busting can only be identified if we treat them as more conditional than previous studies have done, and a gravity model that captures these conditional effects while also addressing several common specification errors. Applying these improvements to data for 1950-2006 significantly alters some of the central findings contained in previous research about sanctions busting.
\end{abstract}

\section{Introduction}

In May 2018, after the US reimposed sanctions on Iran, it sought to compel other states to participate. President Trump warned (on Twitter, of course) that "anyone doing business with Iran will NOT be doing business with the United States." The administration subsequently threatened secondary sanctions on governments that bought Iranian oil, and vowed to punish any commercial actors in the UK, Germany and France who were associated with Instex, a trading system designed to circumvent US sanctions. The effectiveness of these threats against sanctions busting behaviour is far from certain. This is mainly because many states have incentives to shirk. The Europeans were not inclined to join in the sanctions, fearing that they would eliminate the economic benefits that Iran expected from signing the Joint Comprehensive Plan of Action nuclear accord and thus cause the carefully negotiated deal to unravel. In August 2018, the EU adopted its so-called Blocking Statute, which instructs European companies not to follow US sanctions (Jalilvand 2019:5). And via Instex they aimed "to compensate for the American sanctions and protect trade with Iran" (New York Times 8 May 2019). Many non-European states - including China, Russia, India, and even Iran's longstanding enemy Iraq -- also expressed their opposition to the sanctions, either because they had close diplomatic and financial ties to Iran, or because they were wary of being seen to cave in to US pressure, or simply because they feared facing costly economic disruption and higher prices. Iraq even announced plans to set up a system similar to Instex (26 May 2019).

Threats of US punishment arguably also lack credibility, since all of Iran's largest oil importers "are also partners with the United States on major security and diplomatic issues that 
do not involve Iran” (New York Times 22 April 2019). Would the US really be willing to risk progress on these other issues by applying harsh secondary sanctions, even against its traditional allies? The costs to the sender of trying to enforce sanctions can easily outweigh the benefits (Drezner 1999, Early 2012:550). ${ }^{1}$ As of September 2019, some of Iran's trade partners seemed more inclined than others to engage in sanctions busting. In Europe, seven other states said they would join Instex (Guardian 1 July 2019). However, two prominent former National Security Council members lamented 'the Europeans' inability or unwillingness to circumvent US secondary sanctions forcing other countries not to buy Iranian oil and goods" (Simon and Stevenson 2019:25), and the practical effects of Instex will most likely be extremely limited (Jalilvand 2019). In the Middle East, Iraq and Turkey remain determined to maintain trade with Iran. In Asia, initially no state came to Iran's rescue, ${ }^{2}$ but then it appeared that China (with the assistance of Hong Kong) might have restarted purchases of Iranian oil (CNBC 30 May 2019).

This example illustrates an important puzzle: why does sanctions busting vary, so that when sanctions bite, the target state's trade with some third-countries increases but with others decreases? In this paper I argue that to draw meaningful inferences about which factors drive sanctions busting we need to treat the effects of covariates as far more conditional than previous studies have recognised, and that evaluating this conditionality statistically requires an extensive set of interactive terms and a particular form of gravity model. To demonstrate the value of my recommended approach, I re-examine whether the main covariates identified in previous studies effect the busting of US sanctions during the cold war period 1950-1991 and during the post-cold-war period 1992-2006. My empirical results significantly alter some of the central findings contained in previous research about sanctions busting.

\section{Previous studies of third party trade with sanctioned states}

Left to their own devices, it is generally agreed, and hardly surprising, that third party states will be less likely to comply with sanctions, and more likely to sanctions bust, when compliance is costly. Beyond simply not participating in the sanctions, third countries can actively pursue measures to boost the target state's imports and exports. At the microlevel, firms might ignore the sanctions and pursue business-as-usual with the target, or they can go

\footnotetext{
${ }^{1}$ While the overall costs to the sender of applying sanctions can undoubtedly be high, studies disagree about the level of purely economic costs incurred (Hufbauer, Elliott, Cyrus and Winston 1997, Drezner 1998, Yang et al 2004).

${ }^{2}$ https://www.oxfordenergy.org/wpcms/wp-content/uploads/2019/03/Iranian-Energy-after-the-Re-Impositionof-US-Sanctions.pdf, p.7.
} 
further and attempt to circumvent the sanctions by shifting their operations and rerouting trade with the target via third countries (Morgan and Bapat 2003, McClean and Whang 2010).

Most of the previous studies that have examined the effects of US sanctions on trade between target and third-states concentrate almost exclusively on the question of whether trade levels increase or decrease, and pay little or no attention to explaining cross-national variation. Caruso (2003) examines the impact of unilateral US sanctions on trade between target countries and other G-7 countries during 1960-2000. He found that G7-target trade rises significantly when the US imposes moderate sanctions but falls significantly when the US imposes severe sanctions. Caruso speculates that US competitors, even its allies, are more likely to bust its sanctions (e.g. Reagan's sanctions on Nicaragua in the 1980s) (2003:19) but he doesn't explicitly test this claim. Yang et al (2004) investigate how US sanctions affected target trade with the EU and Japan during 1980-98. In some instances US sanctions reduced the target's trade with Japan as well as with the EU, whereas in others they caused an expansion of trade (2004:56). The authors speculate about what explains this variation, but they don't test their ideas by including the relevant political variables in their model. Nor do they attempt to explain variation of target state trade with the different EU states or with states beyond the EU other than Japan.

Kaempfer and Ross (2004) argue that third party states that are larger, richer, and closer to a target state trade more with that state and thus their domestic groups have more to lose from the disruptive effects of sanctions. For these states it is more politically costly to restrict trade via sanctions, so they will tolerate or actively facilitate sanctions busting. Kaempfer and Ross infer support for their hypothesis by comparing the effects of size, wealth and proximity of third party states on South Africa's bilateral trade in 1981-1985 versus 1986-1990, but they dont directly evaluate any political or institutional variables that might explain cross-national variation.

Hufbauer, Schott and Elliott (HSE) (2007) evaluated how US sanctions impacted target state trade with third states in 1999. They found that US sanctions "often diminish the trade of target countries with all [their] partners" (2007:203), but "in an almost equal number of instances" and especially for more severe sanctions the target's trade with third-states actually increases (2007:207). However, their analysis was not designed to explain cross-national variation. Building on HSE (2007), Yang et al (2009) study the impact of US unilateral economic sanctions from 1980-2003. They find that US sanctions reduce target trade with EU states, but that over time sanctions busting gradually increases. Although they note that the effect differs significantly across the target's EU trade partners (2009:1236) they don't seek to 
explain this variation by introducing political variables, and they don't compare the extent of sanctions busting by EU states to sanctions busting by non-EU states.

Several studies by Early $(2009,2012)$ stand as the most ambitious effort to explain variation in third country bilateral trade with target states as a function of political and economic relationships. Early argues that how third country trade responds to sanctions depends on power, rivalry and alliance relationships. For example, we would expect that its sheer power would enable the US to achieve "coercive cooperation" (Martin 1992) from much weaker third states. We would also expect that third states that are rivals of the target state, and thus eager to see it weakened, would be less likely to bust sanctions, whereas third states that are rivals of the US and thus supportive of the US's enemies would be enthusiastic sanctions busters.

Likewise, a defense pact represents a commitment to aid an ally - and certainly to refrain from exacerbating its harm -- when they are materially threatened. Protecting a sanctioned state's economic health (and thereby its security) by not joining the sanctions regime and allowing or even encouraging firms to engage in sanctions busting from its territory increases the likelihood that the sanctioned state will reciprocate when called upon. It also signals to all its other allies the credibility of a third state's commitments. Sanctions busting for an ally also makes good domestic political sense since the domestic business groups it benefits have substantial political clout. We would also expect US allies to be sensitive to their security commitments and thus more reluctant to bust US sanctions. Early finds no support for the effects of rivalries, but that, indeed, third states that have defense pacts with the target are more likely to act as "black knights" and bust sanctions. Counterintuitively, though, he finds that "close allies of the sender are more likely to bust its sanctions" (2009:61).

In later work, Early extends his argument in order to explain this surprising result that the US appears to have relatively less leverage over its allies than it does over other states. He proposes that the effect of alliance ties with the sender is conditional on the ally's trade dependency. Early measures this as tradeshare, the ratio of an ally's dyadic trade with a given state to the ally's total trade. Conceptually, this makes good sense since it is costlier to cut trade with a major partner than a minor partner, and compared to trade openness -- the ratio of a state's total trade to its GDP -- "tradeshare appears much more effective at capturing the dependency aspects of trading relations" (Gartke and Li 2003:561). In short, "third parties will cooperate with senders when the costs are low, but use their alliance relationships as cover to sanctions bust when the commercial benefits are high" (Early 2012:547). And because the US values the long-term benefits that defense pacts with its allies provide, it is less able to coerce 
them to comply with sanctions. Firms from anywhere in the world that want to engage in sanctions busting and expand their trade with the target will thus be especially attracted to doing so from the territory of either a sender's ally or the target's ally since both sorts of allies are less likely to join the sanctions regime.

Early's results support his hypothesis that when the economic and domestic political costs of compliance are high for a third state (i.e. when it conducts a high proportion of its total trade with the target), allies will exploit the lack of US leverage and engage in sanctions busting. Amongst his other findings, the most notable are that both rivalry and military disputes between the target and a third state reduce sanctions busting, as does US relative power, that sanctions busting is more likely for jointly democratic dyads, and that the willingness of third states to bust US sanctions grew after the end of the cold war (Early 2012:566).

\section{A greater role for conditional effects}

This paper aims to improve the study of sanctions busting in two ways. First, I offer a theoretical framework that recognises how the effects of covariates on sanctions busting can only be identified if we treat them as more conditional than previously studies have done, and second, I construct a more appropriately specified gravity model of trade that allows us to identify these effects.

My main argument can be summed up in three sentences. The defining feature of a "black knight" state is that it deliberately steps in and trades with a sanctioned state more than it would normally do. Any claim about what accounts for variation in sanctions busting therefore demands an explicit comparison between a covariate's effect on dyadic trade when sanctions are in place and its "normal" effect when sanctions are absent. And proper model specification must reflect this inherently comparative reasoning with the inclusion of appropriate interaction terms.

To get a clear sense of the puzzle and the improvements I'm proposing, Figure 1 depicts the bilateral trade of hypothetical state $\mathrm{T}$ with the US and with three other third states, both before (time $\mathrm{t}-1$ ) and after (time $\mathrm{t}$ ) the US imposes sanctions on state T. 

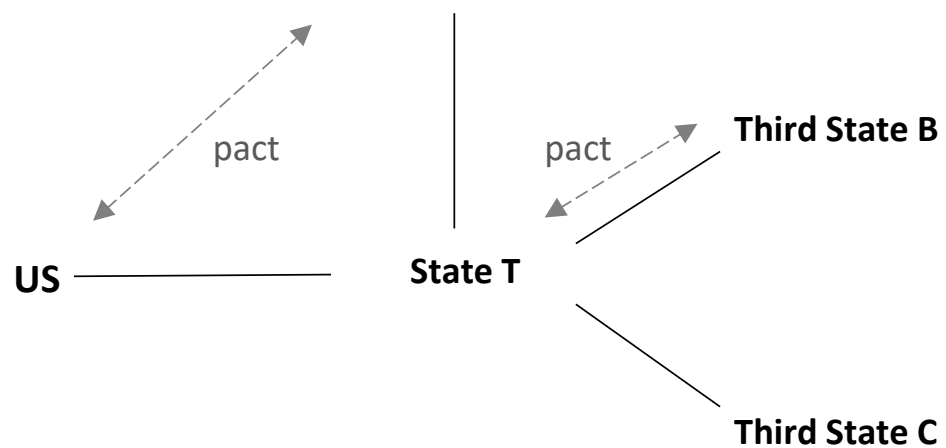

Time $\mathrm{t}$

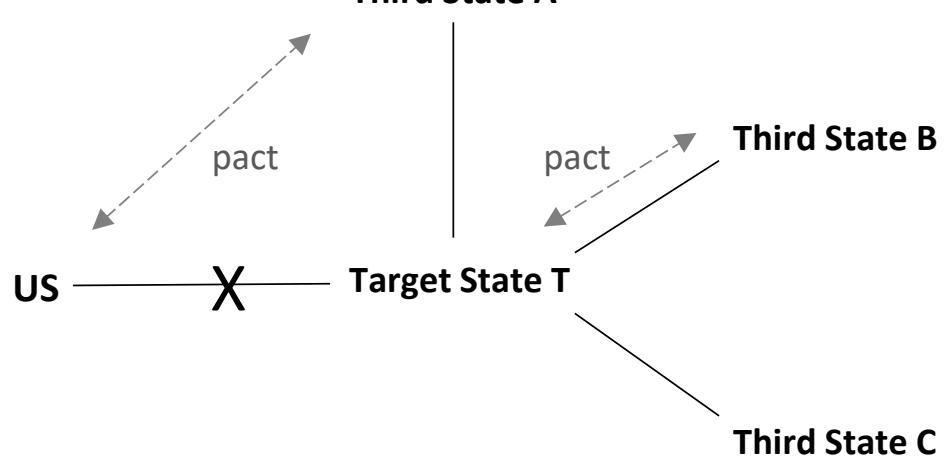

Figure 1 Bilateral trade between a sender, target state and three third states

Dashed grey lines indicate the presence of a defense pact. For time $t$ the line indicating bilateral trade between state T and the US is crossed out to show that the US has imposed sanctions.

For the purposes of this paper we are not interested in the level of US trade with state $\mathrm{T}$ or whether US sanctions reduced US trade with state $\mathrm{T}$. Nor are we interested in two important questions that many other studies have addressed, whether US sanctions are a success in terms of producing either regime change or human rights improvements in the target state (Lektzian and Souva 2007, Bapat and Morgan 2009, McLean and Whang 2010, EscribaFolch and Wright 2010, Grauvogel and von Soest 2014, Bapat and Kwon 2015, Peksen 2019). The variation we want to explain is the level of trade between state $\mathrm{T}$ and the three third countries, each of which the US can pressure to prevent sanctions busting. As discussed above, the leading explanatory variables are defense pacts between the target and third states (defense), defense pacts between the US and third states (defenseUS), trade dependence of the third state 
on the target (tradeshare), the sheer power of the US relative to the third state, dyadic democracy, and whether the sanctions occurred during the cold war.

Consider how sanctions alter the "normal" effects of defense pacts between a third state and the target, and between the third state and the US. Numerous third states were members of one or both types of pact well before the US chose to impose sanctions. For example: Canada had a defense pact with Turkey continuously since 1951, whereas US sanctions on Turkey began in 1974; Canada and the US had a defense pact at least as far back as 1950, ten years before the US sanctioned Cuba. Any claims about the effects of alliance relationships on sanctions busting only have bite if we can discern a significant change in firm and state behaviour once sanctions take hold, which requires a direct comparison of the effects across the two periods. Previous research has established that alliances increase bilateral trade (Gowa and Mansfield 1993, Mansfield, Milner and Rosendorff 2000). But prior to 1974, the CanadaTurkey defense pact probably had a relatively modest effect on their bilateral trade since Canada was not being called upon to deliver its side of the deal and come to Turkey's aid. If allies of target states tend to bust sanctions, we would expect the pact to have a much greater effect after 1974, when Turkey faced the consequences of US sanctions and needed Canadian assistance.

Likewise, prior to 1960, the Canada-US defense pact probably had a relatively modest effect on bilateral trade between Canada and Cuba. US firms, or firms from elsewhere in the world, would have had no particular reason to relocate their operations to Canada in order to reach Cuban markets. It is doubtful that the US was trying to limit trade between Canada and Cuba prior to its imposition of sanctions in 1960, but even if it was, once sanctions were in place those efforts increased dramatically. If allies of the sender are indeed most likely to bust sanctions, then the effect of the Canadian-US defense pact on Canada-Cuba trade should have increased markedly as of 1960 as Canada exploited the lack of US leverage and sheltered firms that flocked there to circumvent US sanctions.

Referring back to Figure 1, to evaluate the effects of the Canada-Turkey pact on Canada's sanctions busting we must therefore explicitly compare the pact's "normal" effect at time t-1 when sanctions aren't in place to its effect at time t. For model specification, this involves including along with all the other covariates the constituent terms defense, defenseUS, and sanction, as well as the interactive terms defense*sanction and defenseUS*sanction. Including all of the necessary terms allows us to test the following hypothesis: 
H1 a target's allies are more likely to bust sanctions: a defense pact between a target state and a third state has a larger positive effect on their bilateral trade when US sanctions are in place

Sanctions also alter the effects of several other main explanatory variables. For example, consider the level of a third state's economic dependency on a target state (tradeshare), defined as Trade $_{\text {dyad }} /$ TotalTrade $_{3 r d S t a t e}$. The effect should be greater when sanctions are in place. Firms in a target state hit by a sender's sanctions need to search for and develop alternative markets for their imports and exports. As Early notes (2009:56), this process is costly, so they are likely to concentrate their efforts and intensify interactions with those states which already have the relatively deepest trade links to the target. Without sanctions, a third state's dependence might still matter for bilateral trade levels - for the simple reason that last year's close trade partner is likely to be this year's close trade partner - but it doesn't elicit any heightened strategic behaviour by firms or any particular expansion of trade. For example, the Bahamas was more dependent on Libya than any other third state in the years leading up to the 1978 US sanctions on Libya. But prior to 1978, firms in Libya werent working frantically to redirect their trade with the US towards the Bahamas. If the effect of interdependence is unchanged - if "normal" trade between highly interdependent dyads (i.e. at time t-1 in Figure 1) looks just like their post-sanctions trade - this would suggest that economic interdependence per se doesn't explain cross-national variation in sanctions busting. To find out, we need to include not only the constituent terms tradeshare and sanction, but also the interaction term tradeshare* sanction. $^{2}$

While highly dependent third states are attractive locations once sanctions commence, Early claims that a highly dependent third state with a US defense pact is where businesses will really flock. If so, then the interactive term tradeshare*defenseUS should be much larger after the imposition of sanctions since it is the supposed inability of the US to enforce compliance on its allies that gives the term its explanatory power. Prior to sanctions, the US is not trying to enforce anything and there is nothing for the third country to exploit. To give a concrete example, the US sanctioned Libya from 1978 to 2004, and both Turkey and Italy - two of the countries most economically dependent on Libya -- had defense pacts with the US from 19502012. Prior to 1978, Turkey-Libya and Italy-Libya trade might have been affected by their defense pacts with the US, and this relationship was likely affected by their trade dependence on Libya, but if this conditional relationship explains anything about sanctions busting then we should see a boost in the conditional effect after 1978. To capture this conditionality requires 
the three-way interaction tradeshare ${ }^{*}$ defenseUS*sanction. With all the terms in place we can test the following hypotheses:

H2 A target's more dependent trade partners are more likely to bust sanctions: a third state's economic dependency on bilateral trade with the target should have a larger positive effect after the imposition of sanctions

H3 US allies are more likely to bust sanctions: a defense pact between a third state and the US, conditional on economic dependence, should have a larger positive effect on the target's trade with the third state after the imposition of sanctions

Conditionality should also apply to both US coercive power and dyadic democracy, and perhaps also to military disputes. The effect of US coercive power on bilateral trade should be much greater when sanctions are in place since only then is the US actually trying to coerce compliance with something. And whether democratic third states are especially prone to bust sanctions when the US targets fellow democracies can only be determined once we explicitly control for whether democratic dyads already "normally" tend to trade more with each other regardless of sanctions (Mansfield, Milner and Rosendorff 2000). While the evidence that dyads involved in military disputes will trade less than other dyads is mixed (Li and Sacko 2002, Kastner 2007), Caruso (2003) argues that for purely financial reasons firms will avoid doing business with target and third states involved in military conflicts, whereas Early (2012) argues that for geopolitical reasons third states involved in a military dispute with the target state should be eager to weaken it and thus particularly reluctant to bust US sanctions. To discern the effect of each of these variables on sanctions busting we need to directly control for their effect on the "normal" amount of target-third-state dyadic trade. I therefore test the following hypotheses:

H4 US coercive power prevents sanctions busting: relative US power should have a larger negative effect on bilateral trade between target states and third states when sanctions are in place

H5 Democracies help democracies: dyadic democracy should have a larger positive effect on trade between target states and third states when sanctions are in place

H6 Military disputes deter sanctions busting: military disputes between target states and third states should have a greater negative effect on their bilateral trade when sanctions are in place 
Finally, the effects of many covariates are likely to be conditional on system polarity and the end of the cold-war. The willingness and ability of other states to oppose US demands, the relative importance of alliance relationships, the relevance of sheer power in a more globalised world, the attraction associated with dyadic democracy, the mobility and thus sanctions busting ability of firms, arguably the collapse of bipolarity altered all of these (Morrow, Siverson and Tabares 1998:652, Early 2009:68, Brooks and Wohlforth 2008, Ikenberry et al 2009). Simply including a "coldwar" dummy does not capture this conditionality; it shifts the overall predicted level of trade up or down as polarity changes, while assuming that the effects of the other covariates remain constant. Instead, one needs to either split the sample by time period or add a battery of interaction terms (Gowa 2011, Gowa and Mansfield 1993, Morrow, Siverson and Tabares 1998, Mansfield and Bronson 1997).

H7: The end of the cold war altered the effects of covariates on trade between target states and third states

To be clear, this article is certainly not the first to highlight the importance of conditional effects and the need for interaction terms to evaluate them. That ground has already been covered in detail (Brambor, Clark and Golder 2006), and several studies of bilateral trade include interactions to assess the effects of covariates (Mansfield and Bronson 1997, Mansfield, Milner and Rosendorff 2000, Bayer and Rupert 2004, Kastner 2007, Carnegie 2014). My claim is that to improve our understanding of sanctions busting we must pay much greater attention to the conditional effects of covariates.

\section{Data and methods}

In order to evaluate the effects on sanctions busting of any covariate, several steps are necessary. First, it is essential to directly compare the level of trade in years with and without sanctions within a single gravity model that includes all of the relevant covariates. Gravity models dominate the study of international trade. Based on an analogy to Newton's law of universal gravitation, we should expect that the level of bilateral trade for any two countries is directly proportional to the product of their sizes (GDPs) and inversely proportional to the trade frictions or barriers that separate them (e.g. distance, language, hostility etc.). Fitting a complete gravity model of bilateral trade levels for all dyads and years is standard practice. Examples include evaluating the effects of WTO membership (Rose 2004, Carnegie 2014), 
alliances (Gowa and Mansfield 1993, Bayer and Rupert 2004), regime type (Mansfield, Milner and Rosendorff 2000), defense pacts (Long 2003), armed conflict (Long 2008), similarity of political interests (Kastner 2007) and most importantly, of sanctions (Hufbauer et al 1997, Caruso 2003, HSE 2007, Slavov 2007, Yang et al 2004, 2009).

Using the estimated coefficients from the fitted model, one then examines the counterfactual by calculating the difference between two sets of predicted bilateral trade flows, "assuming first the absence of sanctions and then the presence of sanctions" (HSE 2007:207, see also Yang 2004). In Stata, this is done quickly by using the -margins-- command with the -contrast-option.

To obtain reliable estimates about the determinants of sanctions busting, I recommend that analysts employ a particular form of the gravity model because it has several advantageous features. In their review of problems commonly found in gravity models, Baldwin and Taglioni (2007) assign medals to the worst specification errors. The gold medal goes to ignoring bias caused by the correlation between included and unobservable determinants of bilateral trade, and "the most promising approach [to mitigate such endogeneity bias], lacking compelling instrumental variables, is to include country-pair fixed effects" (Head and Mayer 2014:36, see also Baldwin and Taglioni 2007:805 and Baier and Bergstand 2007). I return to this issue below when discussing robustness checks.

Silva and Tenreyro (2006) have shown that log-linear models - like those used in all the gravity model studies cited above -- are inherently problematic because of heteroskedasticty. Their experiments show that "overall, except under very special circumstances, estimation based on the log-linear model cannot be recommended" (2006:648). Various methods of obtaining robust or adjusted errors don't suffice because they only affect the estimated standard errors and have no effect at all on the estimates of the parameters. Instead of log-linear models of trade flows, to get consistent estimates analysts should instead fit the gravity equation using a Poisson model with cluster-robust standard errors (Silva and Tenreyro 2006:645). Cluster-robust standard errors also address potential problems of overdispersion and serial correlation (Cameron and Trivedi 2010:633).

An important additional advantage of fitting a Poisson model is that it "provides a natural way to deal with zero values of the dependent variable" (Silva and Tenreyro 2006:645). In the Poisson, the dependent variable is simply the level of dyadic trade, which can be zero, whereas with traditional log-linear gravity models the log of zero is undefined. Dropping observations where dyadic trade is zero, as most studies with log-linear models do (HSE 1997, Slavov 2007, Caruso 2003, Long 2008) wastes potentially important information. Adding one 
then logging should be avoided since it makes the results heavily dependent on the scale used and thus effectively meaningless (Head and Mayer 2014:51), and it generates inconsistent estimates of the parameters (Silva and Tenreyro 2006:643). Including cases of zero trade between target and third states is especially important when studying sanctions, since the fundamental objective of the sender is to produce more such cases. For example, the US had a healthy trade relationship with Cuba before it imposed sanctions in 1960. That US-Cuba trade fell sharply thereafter, reaching zero for the period 1963-1976, is enormously important information. Likewise when studying sanctions busting. Of all the third states trading with Libya, the Bahamas was consistently the most dependent throughout the 1970s. After the US imposed sanctions on Libya in 1978, its trade with the Bahamas eventually dried up, dropping to zero from 1988 onwards. Why Libya's trade with the Bahamas reduced to zero whereas its trade with other third states remained robust or even expanded is precisely the sort of puzzling variation that requires explanation.

To address the problems identified above, I fit Poisson models of dyadic trade, specifying dyadic fixed effects and robust standard errors clustered by dyad. All variables are measured yearly. I use data from HSE (2007) to examine the effects that US sanctions had on third-state trade with target states from 1950 to 2006. The unit of observation is the dyad-year, with dyads composed of a state that at some point was the target of one of the 122 episodes of US sanctions and every other "third" state in the world apart from the US. There are a total of 71 different target states, and 199 different third states. The main dependent variable is the value of total dyadic trade (imports plus exports) each year as recorded in the Correlates of War Trade Dataset 4.0 (Barbieri and Keshk 2016). Most studies of sanctions use this sort of combined measure because US sanctions can hit target state imports as well as exports. But since my hypotheses should apply to both bilateral imports and bilateral exports between target states and third states, I also fit models with each of these as the dependent variable. Ignoring missing values, the dataset is an unbalanced panel that contains 538,666 observations.

For the independent variables, a dummy sanction takes the value of one in years when a state was the target of US sanctions. Two core gravity variables, found in nearly all previous studies of trade flows, are the logged products of the dyadic states' real GDPs and their populations (Gleditsch 2014). I exclude several other potential core variables such as dyadic distance, contiguity, shared official language, past colonial relationship, and whether both members of the dyad are islands or landlocked because their values remain constant over time and with the fixed effects design they would just drop out of the analysis. 
For the main variables of interest, I use data from Gibler (2009) to code whether the third country has a defense pact with either the (eventual) target state (defense) or with the US (defenseUS). The variable tradeshare is constructed from the COW Trade Dataset and measures the trade dependence of the third state on the (eventual) target, lagged by one year to avoid endogeneity. For the US's coercive power, powerUS codes the (logged) relative military and economic strength (CINC) of the United States compared to the third state (NMC Version 5.0 update of Singer 1987). The dummy democ takes the value of one if both the (eventual) target and third state are democracies (Boix, Miller and Rosato 2012). The dummy variable MID measures whether the third state is engaged in a militarized international dispute with the (eventual) target (Maoz et al 2018).

As discussed above, to capture how the effects of defense pacts (between target states and third states and between third states and the US), US coercive power, economic interdependency between third states and target states, dyadic democracy and military conflict are conditional on sanctions, I interact each of these with the sanction dummy. To capture the effect of defense pacts with the US, conditional on both sanctions and trade dependence, I include the two-way interactive term defense US*tradeshare and the three-way interaction term sanction*defenseUS*tradeshare. For (eventual) target state $i$, third country $j$, in year $t$, and ignoring estimated coefficient symbols for ease of presentation, we can represent the dyadic fixed effects Poisson model as follows:

$$
\begin{aligned}
& \mathrm{TRADE}_{\mathrm{ijt}}=\exp \left\{\ln \left(\mathrm{GDP}_{\mathrm{it}} * \mathrm{GDP}_{\mathrm{jt}}\right)+\ln \left(\text { Pop }_{\mathrm{it}} * \mathrm{Pop}_{\mathrm{jt}}\right)+\text { Sanction }_{\mathrm{it}}+\text { Defense }_{\mathrm{ijt}}+\text { DefenseUS }_{\mathrm{jt}}\right. \\
& + \text { Tradeshare }_{\mathrm{ijt}}+\text { DefenseUS }_{\mathrm{jt}}{ }^{\text {Tradeshare }} \mathrm{ijt}+\text { PowerUS }_{\mathrm{jt}}+\text { Democ }_{\mathrm{ijt}}+\mathrm{MID}_{\mathrm{ijt}}+ \\
& \text { Sanction }_{\mathrm{it}} *\left[\text { Defense }_{\mathrm{ijt}}+\text { DefenseUS }_{\mathrm{jt}}+\text { Tradeshare }_{\mathrm{ijt}}+\text { DefenseUS }_{\mathrm{jt}} * \text { Tradeshare }_{\mathrm{ijt}}+\text { PowerUS }_{\mathrm{jt}}\right. \\
& \left.\left.+\operatorname{Democ}_{\mathrm{ijt}}+\mathrm{MID}_{\mathrm{ijt}}\right]+\operatorname{Dyad}_{\mathrm{ij}}\right\}^{*} \exp \left(\mathrm{e}_{\mathrm{ijt}}\right)
\end{aligned}
$$

To test H7, ideally we would interact most of the terms in the above equation with a postcoldwar dummy. But data limitations made this impossible, as the multicollinearity produced by all the extra interaction terms caused several to drop out and prevented convergence. So as a second best option, I fit one model for the cold war period (1950-1991) and one for the post-cold war period (1992-2006).

Table 1 reports the results. In a Poisson model, with either cross-section or panel data, the estimated regression coefficients can be interpreted as semi-elasticities (Cameron and Trivedi 2010:346\&639) that indicate the proportionate change in the dependent variable produced by a one unit change in the independent variable. In other words, a one unit increase in $\mathrm{x}_{\mathrm{j}}$ will change dyadic trade by $100 \beta_{\mathrm{j}}$ percent. 


\begin{tabular}{|c|c|c|c|c|c|c|}
\hline & \multicolumn{2}{|c|}{ Total bilateral trade } & \multicolumn{2}{|c|}{$\begin{array}{c}3^{\text {rd }} \text { state imports } \\
\text { from target }\end{array}$} & \multicolumn{2}{|c|}{$\begin{array}{c}3^{\text {rd }} \text { state exports } \\
\text { to target }\end{array}$} \\
\hline & Model 1 & Model 2 & Model 3 & Model 4 & Model 5 & Model 6 \\
\hline & $1950-1991$ & $1992-2006$ & $1950-1991$ & $1992-2006$ & $1950-1991$ & $1992-2006$ \\
\hline Sanction & $\begin{array}{c}0.168^{*} \\
(0.0843)\end{array}$ & $\begin{array}{l}-0.328 * * \\
(0.0638)\end{array}$ & $\begin{array}{c}0.162 \\
(0.100)\end{array}$ & $\begin{array}{c}-0.412 * * \\
(0.0832)\end{array}$ & $\begin{array}{c}0.169 \\
(0.0994)\end{array}$ & $\begin{array}{l}-0.249 * * \\
(0.0862)\end{array}$ \\
\hline Defense & $\begin{array}{l}0.365 * * \\
(0.0825)\end{array}$ & $\begin{array}{l}0.155 * * \\
(0.0567)\end{array}$ & $\begin{array}{l}0.396 * * \\
(0.0821)\end{array}$ & $\begin{array}{c}0.0919 \\
(0.0635)\end{array}$ & $\begin{array}{l}0.338 * * \\
(0.104)\end{array}$ & $\begin{array}{l}0.237 * * \\
(0.0643)\end{array}$ \\
\hline DefenseUS & $\begin{array}{c}0.426 * * \\
(0.131)\end{array}$ & $\begin{array}{c}0.237^{*} \\
(0.0938)\end{array}$ & $\begin{array}{c}0.494 * * \\
(0.146)\end{array}$ & $\begin{array}{l}0.265^{*} \\
(0.105)\end{array}$ & $\begin{array}{l}0.314 * \\
(0.135)\end{array}$ & $\begin{array}{c}0.162 \\
(0.114)\end{array}$ \\
\hline Tradeshare & $\begin{array}{c}2.903 * * \\
(0.659)\end{array}$ & $\begin{array}{c}3.493 * * \\
(0.739)\end{array}$ & $\begin{array}{c}2.467 * * \\
(0.723)\end{array}$ & $\begin{array}{c}3.436 * * \\
(0.904)\end{array}$ & $\begin{array}{c}3.296 * * \\
(0.685)\end{array}$ & $\begin{array}{c}3.579 * * \\
(0.675)\end{array}$ \\
\hline PowerUS & $\begin{array}{l}-0.648 * * \\
(0.0869)\end{array}$ & $\begin{array}{l}0.0272 \\
(0.102)\end{array}$ & $\begin{array}{l}-0.590 * * \\
(0.0960)\end{array}$ & $\begin{array}{c}0.122 \\
(0.121)\end{array}$ & $\begin{array}{l}-0.705 * * \\
(0.0936)\end{array}$ & $\begin{array}{c}-0.0710 \\
(0.105)\end{array}$ \\
\hline Democ & $\begin{array}{l}-0.0297 \\
(0.0468)\end{array}$ & $\begin{array}{l}-0.122 * * \\
(0.0369)\end{array}$ & $\begin{array}{l}-0.0578 \\
(0.0565)\end{array}$ & $\begin{array}{l}-0.147 * * \\
(0.0345)\end{array}$ & $\begin{array}{l}-0.00353 \\
(0.0507)\end{array}$ & $\begin{array}{l}-0.0898 \\
(0.0590)\end{array}$ \\
\hline MID & $\begin{array}{c}-0.0516 \\
(0.0552)\end{array}$ & $\begin{array}{c}0.0477 \\
(0.0353)\end{array}$ & $\begin{array}{c}0.0369 \\
(0.0670)\end{array}$ & $\begin{array}{c}0.0589 \\
(0.0446)\end{array}$ & $\begin{array}{c}-0.143 * \\
(0.0621)\end{array}$ & $\begin{array}{c}0.0345 \\
(0.0264)\end{array}$ \\
\hline Defense*Sanction & $\begin{array}{c}-0.216 * * \\
(0.0667)\end{array}$ & $\begin{array}{l}-0.123 \\
(0.115)\end{array}$ & $\begin{array}{c}-0.257 * * \\
(0.0672)\end{array}$ & $\begin{array}{c}-0.0485 \\
(0.151)\end{array}$ & $\begin{array}{c}-0.178^{*} \\
(0.0841)\end{array}$ & $\begin{array}{c}-0.234 * \\
(0.111)\end{array}$ \\
\hline DefenseUS*Sanction & $\begin{array}{l}-0.0965 \\
(0.0624)\end{array}$ & $\begin{array}{l}0.166 * * \\
(0.0626)\end{array}$ & $\begin{array}{c}-0.118 \\
(0.0766)\end{array}$ & $\begin{array}{c}0.0888 \\
(0.0753)\end{array}$ & $\begin{array}{l}-0.0669 \\
(0.0734)\end{array}$ & $\begin{array}{l}0.310 * * \\
(0.0751)\end{array}$ \\
\hline PowerUS*Sanction & $\begin{array}{c}-0.00092 \\
(0.0197)\end{array}$ & $\begin{array}{c}0.0460 * * \\
(0.0172)\end{array}$ & $\begin{array}{l}-0.0180 \\
(0.0231)\end{array}$ & $\begin{array}{c}0.0365 \\
(0.0214)\end{array}$ & $\begin{array}{c}0.0146 \\
(0.0241)\end{array}$ & $\begin{array}{c}0.0593 * * \\
(0.0229)\end{array}$ \\
\hline Democ*Sanction & $\begin{array}{c}-0.242 * * \\
(0.0585)\end{array}$ & $\begin{array}{l}-0.144 * \\
(0.0578)\end{array}$ & $\begin{array}{c}-0.162 * * \\
(0.0581)\end{array}$ & $\begin{array}{c}-0.0199 \\
(0.0708)\end{array}$ & $\begin{array}{l}-0.323 * * \\
(0.0796)\end{array}$ & $\begin{array}{c}-0.284 * * \\
(0.0702)\end{array}$ \\
\hline Tradeshare*Sanction & $\begin{array}{c}0.632 \\
(0.566)\end{array}$ & $\begin{array}{c}0.267 \\
(0.759)\end{array}$ & $\begin{array}{c}0.862 \\
(0.595)\end{array}$ & $\begin{array}{c}-0.0253 \\
(0.788)\end{array}$ & $\begin{array}{c}0.472 \\
(0.620)\end{array}$ & $\begin{array}{c}0.610 \\
(0.839)\end{array}$ \\
\hline DefenseUS*Tradeshare & $\begin{array}{l}-0.852 \\
(0.977)\end{array}$ & $\begin{array}{c}0.416 \\
(0.535)\end{array}$ & $\begin{array}{l}-0.687 \\
(0.999)\end{array}$ & $\begin{array}{c}0.463 \\
(0.629)\end{array}$ & $\begin{array}{l}-0.966 \\
(1.035)\end{array}$ & $\begin{array}{c}0.415 \\
(0.547)\end{array}$ \\
\hline DefenseUS*Sanction*Tradeshare & $\begin{array}{c}1.252 \\
(1.054)\end{array}$ & $\begin{array}{c}0.814 \\
(1.236)\end{array}$ & $\begin{array}{c}1.610 \\
(1.031)\end{array}$ & $\begin{array}{l}-0.230 \\
(1.537)\end{array}$ & $\begin{array}{c}0.811 \\
(1.184)\end{array}$ & $\begin{array}{c}1.523 \\
(1.171)\end{array}$ \\
\hline MID*Sanction & $\begin{array}{l}-0.0278 \\
(0.0829)\end{array}$ & $\begin{array}{l}-0.0499 \\
(0.0503)\end{array}$ & $\begin{array}{l}-0.198 * \\
(0.0977)\end{array}$ & $\begin{array}{l}-0.0757 \\
(0.0508)\end{array}$ & $\begin{array}{c}0.145 \\
(0.0997)\end{array}$ & $\begin{array}{l}-0.0239 \\
(0.0517)\end{array}$ \\
\hline Observations & 245,726 & 143,778 & 237,628 & 139,394 & 234,295 & 138,222 \\
\hline Dyads & 8,299 & 10,149 & 7,893 & 9,782 & 7,702 & 9,695 \\
\hline
\end{tabular}

Table 1 Fixed effects Poisson models of target-third-state dyadic trade $* * \mathrm{p}<0.01, * \mathrm{p}<0.05$. Estimated coefficients with robust standard errors clustered by dyad in parentheses. Controls for real GDP and population size included but not reported.

Because all of the hypotheses involve conditional effects, it is essential to examine the combined marginal effect of the constituent and interactive terms across a range of values (Brambor, Clark and Golder 2006), and to compare semi-elasticities with and without sanctions. $^{3}$

The results strongly contradict hypothesis one which predicted that the target's allies would act as "black knights" and deliberately trade with the target more than they normally

\footnotetext{
${ }^{3}$ I don't interpret the sanctions variable by itself, since it captures the uninteresting baseline case where defense and defenseUS and powerUS and tradeshare and joint democracy and MID are all zero.
} 
would. In neither the cold-war period nor the post-cold-war period is the semi-elasticity of defense significantly greater during sanctions episodes, and this finding holds for total trade, third-state imports and third-state exports. Moreover, during the cold war period, the proportionate increase in total trade due to a defense pact is significantly lower when sanctions are in place (model $1 \Delta$ semi-elasticity=-.216, p<.01), so that the target's allies actually traded less with it than they normally would. ${ }^{4}$ The same goes for third-state imports from the target (model 3) and third-state exports to the target (model 5), as well as for third-state exports after the cold war (model 6). While target-third-state defense pacts might provide military security, it appears they offer no reassurance that the target's allies will act as black knights to help mitigate the economic damage of US sanctions.

Hypothesis two also enjoys no support. My expectation was that once sanctions took hold, and regardless of any alliance considerations, foreign firms (including those from the sender state) would divert their activities to the target's most dependent trade partners, so that the difference in target-third trade levels between highly dependent and minimally dependent third states would be far greater than normal. However, economic dependency per se has no unconditional effects on sanctions busting, as the difference in semi-elasticities is statistically insignificant during both time periods. This finding holds for total trade as well as for third state imports and exports.

Since my model includes interactive terms for the conditional effects, we can investigate how economic dependence alters target trade with US enemies by setting the value of the US alliance dummy to zero. This reveals the important finding that firms do not flock to highly dependent US enemies when the US imposes sanctions. In both time periods, in the absence of US defense pacts, the effect of economic dependency between third states and target states on their dyadic trade was slightly greater with sanctions but the difference in semielasticities for total trade (290\% v. $354 \%$ and $349 \%$ v. $376 \%$ ) was nowhere near statistically significant. We obtain similar results when the dependent variable is third-state imports or exports.

Hypothesis three posited that while US allies that face higher costs of cutting trade with a third-state might be more (or less) likely to do so if they have a US defense pact, this conditional effect should be larger and positive during sanctions episodes. The results support

\footnotetext{
${ }^{4}$ To obtain the semi-elasticities for covariate $\mathrm{X}$ with and without sanctions, I employed the following Stata command: margins, $\operatorname{dydx}(\mathrm{X})$ at(sanction= $\left.\left(\begin{array}{ll}0 & 1\end{array}\right)\right)$. To directly obtain the difference in these two semi-elasticities, which is the crucial issue, I repeated this -margins- command with the addition of the contrast(atcontrast(ar._at)) option.
} 
my argument but only for the post-cold-war period. The evidence for hypothesis three is best illustrated graphically with a direct comparison of the US defense pact semi-elasticities at different values of third-state economic dependence. Figures 1-3 present the results for total bilateral trade, third-state imports from the target, and third-state exports to the target.
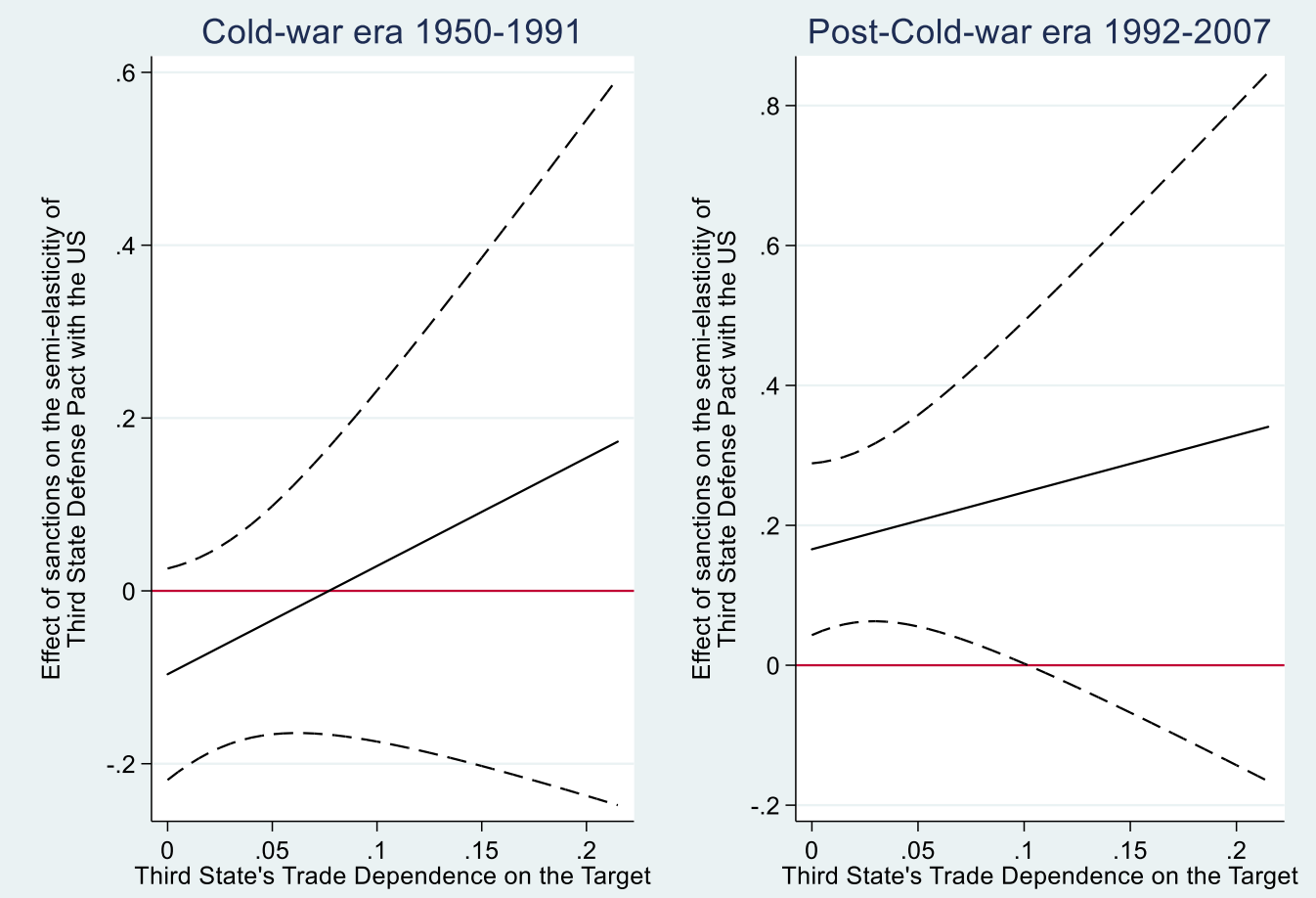

Figure 1 Conditional effects on sanctions busting (total trade) of defense pacts between the US and third states 

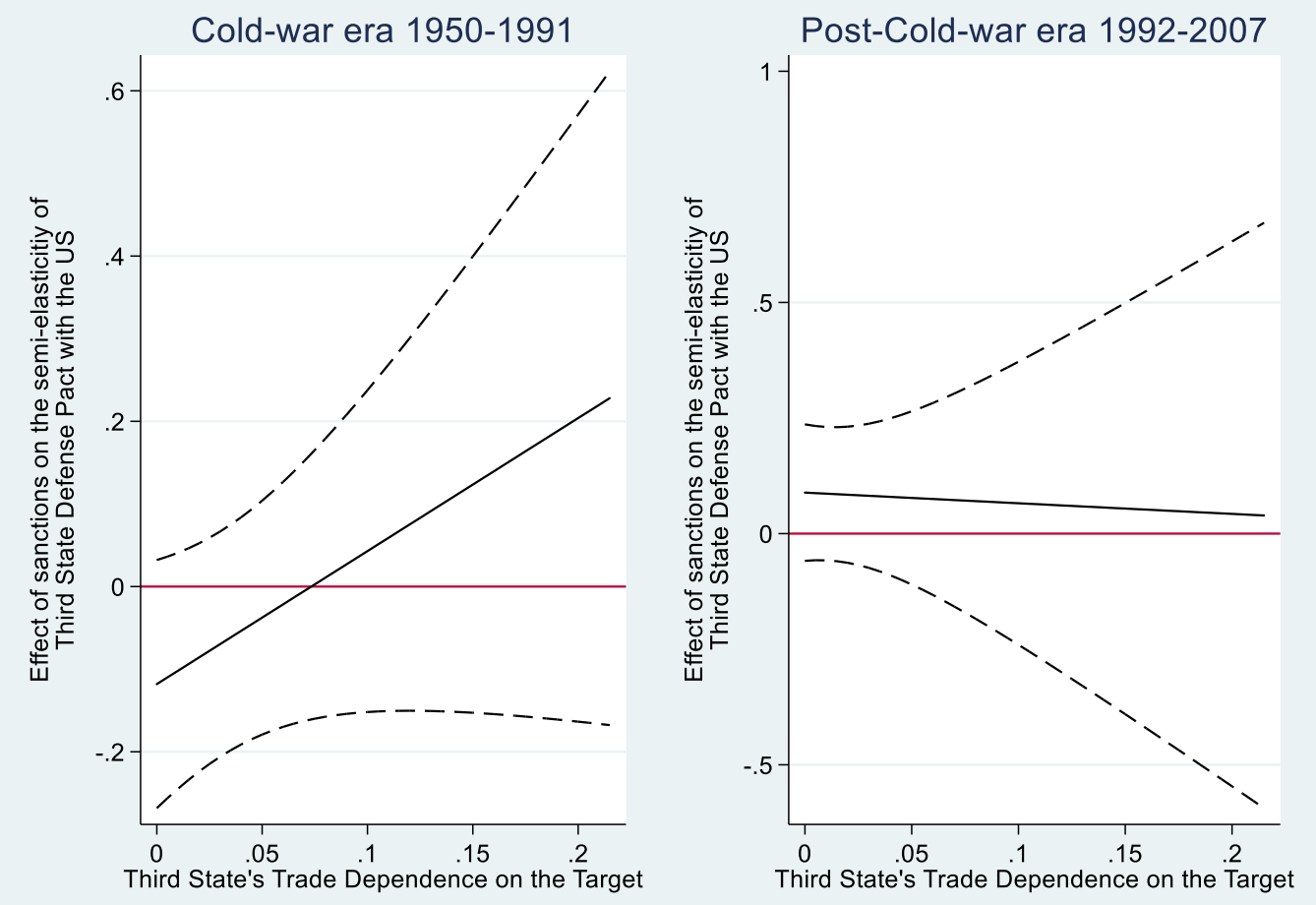

Figure 2 Conditional effects on sanctions busting (third state imports from target) of defense pacts between the US and third states
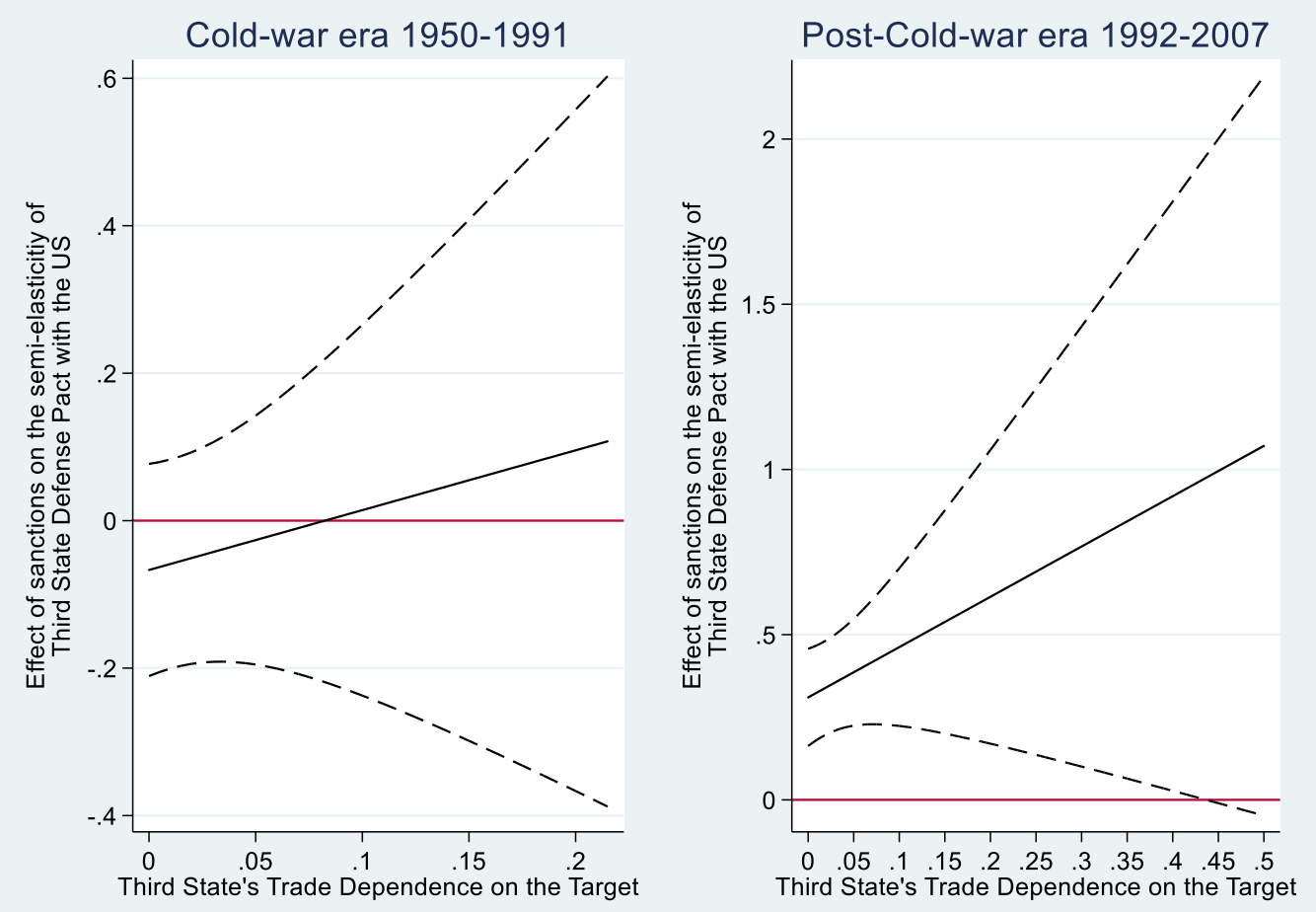

Figure 3 Conditional effects on sanctions busting (third state exports to target) of defense pacts between the US and third states 
As shown in the left panels of Figures 1-3, during the cold war sanctions busting by US allies was not conditional on their trade dependence on the target state. Whether for total trade, thirdstate imports or third-state exports, at each level of trade dependence the difference between the two semi-elasticities is indistinguishable from zero. In the post-cold-war period, however, the US experienced a significant "alliance handicap" conditional on the ally's costs of cutting trade with the target. In the right hand panel of Figure 1 we see the anticipated relationship between costs and sanctions busting manifest in the growing difference between the two semielasticities, and the difference is statistically significant until the level of trade dependence reaches ten percent. At one percent dependence, a US defense pact boosts target-third total trade by $24.1 \%$ without sanctions, but by $41.5 \%$ with sanctions (thus a value of .174 on the yaxis). At 10 percent dependence the handicap is even greater, as an alliance boosts total trade by $28 \%$ without sanctions and by $53 \%$ with sanctions. Although the hypothesis appears not to hold in the most likely situations, where joining the sanctions regime poses the highest costs, this surprising scope condition is virtually irrelevant in substantive terms since in the post-coldwar era US allies have a trade dependence on target states greater than ten percent for only $0.4 \%(640 / 143778)$ of the observations.

Interestingly, the findings regarding a post-cold-war era US alliance handicap are sensitive to the choice of dependent variable. A more refined picture emerges once we distinguish between third state imports and exports. As shown in Figure 2, for 1992-2006 the US alliance handicap did not apply to third state imports, regardless of the third state's trade dependence on the target. But sanctions busting by US allies was much for extensive for third state exports (Figure 3) than for total trade (Figure 1). At one percent dependence, a US defense pact boosts third-state imports from the target by $16.6 \%$ without sanctions, but by $49.1 \%$ with sanctions (thus a value of .325 on the y-axis). At 10 percent dependence the difference in semielasticities is .462. For third state exports, the US alliance handicap remains statistically significant and increases in magnitude all the way up to tradeshare values of $43.5 \%$. In other words, always, since in the post-cold-war era US allies have a trade dependence on target states greater than 43.5 percent for only $0.002 \%$ of the observations.

The results firmly contradict hypothesis four, whether for total trade, third state imports or third state exports. During the cold war, a unit increase in relative US power decreases targetthird-state total trade significantly when sanctions are zero (by 64.8\%), as well as when they are one (by 64.9\%), and the difference is unexpectedly insignificant. What we see here is not 
that during the cold war US coercive power prevented sanctions busting, but rather that weaker states simply traded much less with target states regardless of sanctions. Nor did relative US coercive power prevent sanctions busting after the cold war. Interestingly, for total trade as well as third-state exports, in this period the effect of US power is conditional on sanctions but the difference between the two semi-elasticities is positive, not negative as expected. This indicates that during 1992-2006 relatively weak third states traded more than normal with target states and were thus particularly prone to bust US sanctions.

For hypothesis five, there is no indication that democracies are particularly prone to bust sanctions on other democracies. Across both time periods, and for total trade as well as third state imports and exports, the difference in semi-elasticities for democ with and without sanctions is never positive. In fact, the direction of the effect is often negative. Instead of democratic trade partners of democratic targets serving as attractive locations through which to bust US sanctions, businesses seeking to evade US sanctions tend to flee from them. For the cold war period, joint democracy decreases target-third dyadic total trade by an insignificant amount without sanctions, but by $27.2 \%$ with sanctions. This sizeable difference in semielasticities is significant at the $99.9 \%$ level. Similar results obtain when we switch the dependent variable from total trade to third state imports or exports. The same counterintuitive finding holds in the post-cold-war period for total trade $(-12.2 \%$ v. $-26.5 \%, \mathrm{p}<.05)$, and even more so for third-state exports $(-9.0 \%$ v. $-37.4 \%, \mathrm{p}<.01)$.

For hypothesis six, the results mostly fail to confirm the expectation that the presence of a military dispute decreases sanctions busting. For both time periods, the differences in semielasticities for the $M I D$ variable with and without sanctions are statistically insignificant for total trade and for third-state exports. For third-state imports the differences are significant during the cold war period but insignificant thereafter. There is thus little indication that third states involved in a military dispute with the target state are particularly reluctant to bust US sanctions or that they are treated as especially unattractive locations by risk-averse foreign firms.

Comparing models 1 to 2, 3 to 4, and 5 to 6 confirms hypothesis seven in most respects, bearing in mind the important caveat that the split sample approach I used to evaluate this hypothesis does not allow formal statistical comparisons between the two eras as a fully interactive model would. First, at least in terms of sanctions busting, defense pacts between target and third states proved relatively more useful after the cold war than during the cold war. After the cold war, allies of target states provide no particular economic cushion against US sanctions, whether for total trade or third state imports or third state exports, but during the 
coldwar period things were even worse since these allies were less beneficial trade partners than usual precisely when they could have engaged in sanctions busting. ${ }^{5}$ Second, the curious relative drop in trade between democratic trade partners of democratic targets during US sanctions was greater during the cold war than in the more recent period. In other words, democratic trade partners of democratic targets were even less inclined to bust US sanctions during the cold war than they were afterwards.

Third, the end of the cold war greatly diminished the ability of the US to prevent its allies from busting its sanctions. During the cold war, the US did not experience an "allianceimposed restraint", whether for total trade or third-state imports or exports, regardless of the level of an ally's trade dependence on the target. Only after the cold war have US allies been more likely than other states to bust its sanctions, and to do so in proportion to their cost of cutting trade with the target. Sanctions busting by US allies manifests in total dyadic trade with target states, and even more so in exports to target states, but not in imports from target states. Finally, the end of the cold-war also changes the effect of US coercive power on how foreign states trade with each other. During the cold war, third states that were much weaker than the US traded far less with target states than did strong third states, regardless of US sanctions. After the cold war, US coercive power to prevent sanctions busting erodes, or at least the inclination of the US to employ that power against weak third states.

\section{Robustness checks}

I tested the robustness of my findings for each of the three dependent variables against five different dyadic fixed effects model specifications that included additional controls. Because dyadic fixed effects might not fully address endogeneity bias, as a further precaution I included time fixed effects. I also tried fitting models with exporter and importer time variant fixed effects, but this produced collinearity problems and the models did not converge. Since the inclusion of dyadic fixed effects limits the inferences we can draw about factors that are mostly or completely time invariant, I also refit the models in Table 1 using random effects rather than fixed effects. The full results for these robustness checks are available in the appendix.

In Table A1, I included two extra core controls that might account for changes in targetthird-state trade and which often appear in gravity models: whether the dyadic states are part of the same regional trade agreement (data from Larch 2008) and whether they share a common

\footnotetext{
${ }^{5}$ For one of the three dependent variables, third-state exports to the target, defense pacts were not more useful after the cold war, as the target's allies continued to trade less than normal with it during sanctions episodes.
} 
currency (data from de Sousa 2012). I hypothesised that tradeshare would help explain variation in sanctions busting because it is costlier to cut trade with a major partner than with a minor partner, but arguably the cost of cutting any trade relationship and thus the expected amount of sanctions busting should be greater the more important trade is to the third state's economy. To account for this possibility, Table A2 therefore includes a measure of the third state's trade openness calculated as totaltrade/GDP (lagged by one year). ${ }^{6}$ It is also possible that the effect of US sanctions and the sanction busting behavior of third-states depends on how much a third-state's GDP relies on the target state's economy. Moreover, since some countries pursue export-led growth strategies and others depend heavily on the importation of intermediate goods, results could differ across the three measures of the dependent variable. The models in Table A3 therefore include the additional control variable reliance $3 T$, which is the ratio of target-third-state trade to third-state GDP.

As mentioned earlier, Caruso (2003) found that more comprehensive sanctions produced greater reductions in the target's trade with the US as well as with other G-7 countries. While this might also apply to third states more generally, more severe sanctions could instead generate a greater shift of trade to third states, much like squeezing a tube of toothpaste harder causes more to flow out. In their dataset, HSE (1990) distinguish between sanctions that interrupt finance between the target and sender $(\mathrm{F})$, exports from the sender to the target $(\mathrm{X})$, and imports by the sender from the target $(\mathrm{M})$. The most comprehensive sanctions disrupt all three channels at once, and Table A4 captures this with the dummy FXM. To control for the possibility that sanctions-busting is a temporally dependent phenomenon, with both target and third states adjusting more effectively over time to trade disruptions, Table A5 includes the variable timeundersanctions that measures how long the target has been the subject of continuous US sanctions. Table A6 includes year dummies (i.e. time fixed effects) to control for any macroeconomic shocks or general trend that could equally affect all dyads. Table A7 employs random effects rather than fixed effects and includes six time invariant covariates: the natural $\log$ of distance between the dyadic states and whether they are contiguous (Bennett and Stam 2000), whether the dyadic states share a common official language or a past colonial relationship (Mayer and Zignago 2011), and whether both members of the dyad are islands or landlocked (Early 2008).

\footnotetext{
${ }^{6}$ For these two different measures of economic interdependence we should expect opposite signs on the estimated coefficients since trade openness is inherently and inversely related to tradeshare (Gartke and Li (2003).
} 
All the main findings prove robust to these alternative specifications, across the models with fixed effects as well as those with random effects. Only a handful of secondary findings differ, and these differences are due almost entirely to the choice between fixed or random effects. In the additional models with fixed effects, if we use third state exports as the dependent variable, defense pacts between targets and third states usually test out as simply irrelevant to sanctions busting during the cold war rather than positively detrimental for the target state. And with third state imports as the dependent variable, hypothesis two enjoys at least partial support -- for the cold war period, in several of the fixed effects models greater trade dependence of a third state on a target state unconditionally boosts sanctions busting.

With random effects, the evidence for hypothesis seven is weaker, and four of the secondary findings from Table 1 are not robust, although it is important to remember that this might be an example of the "gold medal error" caused by not mitigating endogeneity bias: Both before and after the cold war, defense pacts between target and third states have an insignificant but not a detrimental effect on sanctions busting as measured by third-state exports; The US alliance constraint in the post-cold war era holds for third-state exports but not for total dyadic trade; After the cold war, across all three dependent variables, relatively weak third-states were no more likely than stronger states to bust US sanctions and the presence of a military dispute between the target and third state had no effect on but did not reduce cold war sanctions busting measured as third-state imports.

\section{Conclusion}

When the US sanctions a target state, why do some third states follow suit and cut their trade while others bust sanctions by increasing theirs? This study has sought to improve our understanding of sanctions busting in two ways. First, I offer a theoretical framework that recognises how the effects of covariates on sanctions busting can only be identified if we treat them as more conditional than previously studies have done. Second, I construct a gravity model that captures these conditional effects and also addresses several common specification errors. My recommendation is that these theoretical and methodological improvements become standard practice. To illustrate the advantages of my approach, I applied it to data for 19502006, and the results significantly alter some of the central findings contained in previous studies of sanctions busting.

Contrary to expectations and to extant research, my results suggest that sanctions busting during 1950-2006 is not the result of the target's allies coming to its aid, or of firms flocking to highly dependent third states or to democratic trade partners of democratic targets, 
or away from states engaged in military dispute with the target. Nor has the relative coercive power of the United States enhanced its ability to deter sanctions busting.

My analysis reveals that democratic partners of democratic targets have proven particularly reluctant to bust US sanctions, and that alliance dynamics as well as the role of US coercive power changed considerably after the end of the cold war, at least in terms of their effect on sanctions busting. From 1950-1991, defense pacts proved to be a liability for target states, as their allies traded significantly less with them than normal once the US applied sanctions, whereas for 1992-2006 they had no effect on sanctions busting. By contrast, during the cold war defense pacts between the US and its allies had no effect on sanctions busting; the US did not face an alliance-imposed restraint or handicap, regardless of its allies' trade dependence on the target state. After the cold war, the US's allies became more likely than other states to bust its sanctions, and the extent of their sanctions busting increased in proportion to the potential costs of cutting trade with the target state. Finally, during the cold war sanctions busting by third states bore no relationship to the relative military and economic strength of the United States, whereas after the cold war relatively weak states are more likely to bust US sanctions.

The picture of contemporary sanctions busting that emerges from employing my suggested approach invites future research along several lines. That the allies of target states are not more likely than others to act as black knights could demonstrate the inherent limitations of defense pacts, in that sanctions busting has always been too peripheral a concern to trigger alliance commitments. Even so, this still leaves the question of why the target's defense pacts were actually detrimental to sanctions busting during the cold war. Another outstanding question is why democratic trade partners of a democratic target are more likely than other states to abandon it once US sanctions take effect. The precise mechanisms at work here deserve further study. The causal path could depend mainly on the perceptions and objectives of third-state decisionmakers at the macrolevel and the policies they introduce to promote or restrict trade. Or such policy shifts might be of secondary importance if the real action occurs at the microlevel, where foreign firms deliberately avoid democratic trade partners of democratic targets but less so than they did during the cold war.

More work is also required to explain why, despite its supposed primacy, the US is now less able to prevent its allies and relatively weak states from busting its sanctions. Perhaps it is simply that with the demise of the Soviet threat US allies became less dependent on the alliance relationship and have few compelling reasons to follow US leadership, so that now "the US has less power and influence over others than it exerted during the Cold War" 
(Schweller 2011:179). Ironically, it is possible that the US has come to value the long-term benefits that defense pacts with its allies provide more than its allies value those benefits. In addition, more US allies and weak states have joined international institutions (especially the European Union which enlarged in 1995 and 2004), and by doing so they might constrain or evade US power. Previous work showing that larger organizations are ineffective at preventing their members from busting sanctions (Early and Spice 2015) could be extended to examine the ability of the US to coerce members of different sized organizations into supporting its sanctions both during and after the cold war.

Although it goes beyond the issue of sanctions busting, future studies could investigate why, across all three measures of the dependent variable, the sign on USpower shifts from negative and significant during the cold war to positive and insignificant thereafter. This suggests that in periods of no US sanctions, weak third states used to trade less with (eventual) targets than did strong third states, but no longer. In other words, globalisation or other factors appear to have shifted the trade links of certain countries away from strong states towards weak states.

Another puzzle worth exploring is why some of the secondary empirical findings differed across the three measures of dyadic trade. There are more instances of the US disrupting its exports to targets than its imports from targets, so we might expect sanctions busting to manifest mostly in the form of greater exports from third states. Still, attention could focus on whether it is economically or politically easier to bust US embargoes on its exports than its imports.

Finally, while I took the preventative measures of dyadic fixed effects and time fixed effects to mitigate potential endogeneity bias, more could be done to fully address this important concern. For example, it is plausible that my models suffer from omitted variable bias, or from reverse causality (for example if bilateral trade causes alliances and not vice versa). As Head and Mayer note, "the textbook solution would be to find instrumental variables" (2014:36), in this case particularly for third state defense pacts with target states and with the US.

\section{References}

Baier, Scott and Jeffrey Bergstand (2007) "Do Free Trade Agreements Actually Increase Members' International Trade?” Journal of International Economics 71(1):72-95.

Baldwin, Richard and Daria Taglioni (2007) "Trade Effects of the Euro: a Comparison of Estimators," Journal of Economic Integration 22(4):780-818. 
Bapat, Navin and Bo Ram Kwon (2015) "When Are Sanctions Effective? A Bargaining and Enforcement Framework," International Organization 69:131-62.

Bapat, Navin and T. Clifton Morgan (2009) "Multilateral Versus Unilateral Sanctions Reconsidered: A Test Using New Data," International Studies Quarterly 53:1075-94.

Barbieri, Katherine and Omar M. G. Keshk. 2016. Correlates of War Project Trade Data Set Codebook, Version 4.0. Online: http://correlatesofwar.org.

Bayer, R. \& Rupert, M. (2004) "Effects of Civil Wars on International Trade, 1950-92," Journal of Peace Research 41(6):699-713.

Bennett, D. Scott, and Allan Stam (2000) 'EUGene: A Conceptual Manual,' International Interactions 26:179-204.

Boix, Carles, Michael K. Miller, and Sebastian Rosato (2012) "A Complete Data Set of Political Regimes, 1800-2007," Comparative Political Studies 46(12): 1523-54.

Brambor, Thomas, William Roberts Clark, and Matt Golder (2006) "Understanding Interaction Models: Improving Empirical Analyses," Political Analysis 14: 63-82.

Brooks, Stephen and William Wohlforth (2008) World Out of Balance: International Relations and the Challenge of American Primacy. Princeton: Princeton University Press.

Cameron, A. and Pravin Trivedi (2010) Microeconomics Using Stata (College Station: Stata Press).

Carnegie, Allison (2014) "States Held Hostage: Political Hold-Up Problems and the Effects of International Institutions" American Political Science Review 108(1): 54-70.

Caruso, Raul (2003) "The Impact of International Economic Sanctions on Trade: An Empirical Analysis," Peace Economics, Peace Science and Public Policy 9(2):1-34.

Drezner, Daniel (1998) "Serious About Sanctions," The National Interest 53:66-74.

Drezner, Daniel (1999) The Sanctions Paradox: Economic Statecraft and International Relations (Cambridge: Cambridge University Press).

Early, Bryan (2008) "Landlocked and Island States in the International System, 1950-2005," https://sites.google.com/site/bryanrearly/home/data-sets.

Early, Bryan (2009) "Sleeping with Your Friends' Enemies: An Explanation of SanctionsBusting Trade," International Studies Quarterly 53(1):49-71.

Early, Bryan (2012) "Alliances and Trade with Sanctioned States: A Study of US Economic Sanctions, 1950-2000," Journal of Conflict Resolution 56(3) 547-572.

Early, Bryan and Robert Spice (2015) "Economic Sanctions, International Institutions, and Sanctions Busters: When Does Institutionalized Cooperation Help Sanctioning Efforts?" Foreign Policy Analysis 11:339-360.

Escriba-Folch, Abel and Joseph Wright (2010) "Dealing with Tyranny: International Sanctions and the Survival of Authoritarian Rulers," International Studies Quarterly 54:335-359.

Gartke, E. \& Li, Q. (2003) "Measure for Measure: Concept Operationalization and the Trade Interdependence-Conflict Debate," Journal of Peace Research 40(5):553-71.

Gibler, Douglas (2009) International Military Alliances, 1648-2008. Congressional Quarterly Press.

Gleditsch, Kristian S. (2014) "Expanded Trade and GDP data," version expgdp_v6.0, 9 September 2014.

Gowa, J. (2011). "The Democratic Peace After The Cold War," Economics and Politics 23:153-171.

Gowa, J. \& Mansfield, E. (1993) "Power Politics and International Trade," American Political Science Review 87(2):408-20. 
Grauvogel, Julia and Christian von Soest (2014) "Claims to legitimacy count: Why sanctions fail to instigate democratisation in authoritarian regimes," European Journal of Political Science 53:635-653.

Head, Keith and Thiery Mayer (2014) "Gravity Equations: Workhorse, Toolkit, and Cookbook," CEPII Working Paper No. 2013-27.

Hufbauer, G., Schott, J. and Elliot, K. (1990) Economic Sanctions Reconsidered: History and Current Policy, 2nd ed. Washington, DC: Peterson Institute for International

Economics.

Hufbauer, Gary, Kimberly Elliot, Tess Cyrus and Elizabeth Winston (1997) "US Economic Sanctions: Their Impact on Trade, Jobs, and Wages," Peterson Institute for International Economics.

Hufbauer, Gary, Jeffrey Schott, Kimberly Elliot, and Barbara Oegg (2007) Economic Sanctions Reconsidered. 3rd ed. Washington, DC: Peterson Institute for International Economics

Ikenberry, G. J., M. Mastanduno, and W. C. Wohlforth (eds) (2011) International Relations Theory and the Consequences of Unipolarity (Princeton: Princeton University Press).

Jalilvand, D. (2019) "Back to Square One? Iranian Energy after the Re-Imposition of US Sanctions," Oxford Energy Comment, March 2019.

Kaempfer, William H., and Martin Ross (2004) "The Political Economy of Trade Sanctions against Apartheid South Africa: A Gravity Model Approach," in D. Mitra and A. Panagariya (eds) The Political Economy of Trade, Aid, and Foreign Investment Policies, 233-44. New York, NY: Elsevier.

Kastner, S. (2007) "When Do Conflicting Political Relations Affect International Trade?" Journal of Conflict Resolution 51(4):664-88.

Larch, Mario (2008) "Mario Larch's Regional Trade Agreements Database" from Egger, Peter H. and Mario Larch (2008) "Interdependent Preferential Trade Agreement Memberships: An Empirical Analysis," Journal of International Economics 76(2):384399.

Lektzian, David and Mark Souva (2007) "An Institutional Theory of Sanctions Onset and Success," Journal of Conflict Resolution 51(6):848-71.

Li, Q. \& Sacko, D. (2002) "The (Ir)Relevance of Militarized Interstate Disputes for International Trade," International Studies Quarterly 46(1):11-43.

Long, Andrew (2003) 'DDefense Pacts and International Trade,'” Journal of Peace Research 40:537-52.

Long, Andrew (2008) "Bilateral Trade in the Shadow of Armed Conflict," International Studies Quarterly 52(1): 81-101.

Mansfield, E. \& Bronson, R. (1997) “Alliances, Preferential Trading Arrangements, and International Trade," American Political Science Review 91(1):94-107.

Mansfield, Edward, Helen Milner, and B. Peter Rosendorff (2000) "Free to Trade: Democracies, Autocracies, and International Trade," American Political Science Review 94(2):305-21

Maoz, Zeev, Paul L. Johnson, Jasper Kaplan, Fiona Ogunkoya, and Aaron Shreve (2018). The Dyadic Militarized Interstate Disputes (MIDs) Dataset Version 4.3, http://cow.dss.ucdavis.edu/data-sets/MIDs/mid-level-v4-3-data-files/view.

Martin, L. (1992) "Interests, Power, and Multilateralism," International Organization 46(4):765-792.

Mayer, T. and Zignago, S. (2011) "Notes on CEPII's distances measures: the GeoDist Database," CEPII Working Paper 2011-25. 
McLean, Elena V., and Taehee Whang (2010) "Friends or Foes? Major Trading Partners and the Success of Economic Sanctions," International Studies Quarterly 54 (2):427-47.

Morgan, T. Clifton, and Navin A. Bapat (2003) "Imposing Sanctions: States, Firms, and Economic Coercion," International Studies Review 5 (4):65-79.

Morrow, J, Siverson, R. \& Tabares, T. (1998) "The Political Determinants of International Trade: The Major Powers, 1907-90,” American Political Science Review 92(3):649-61.

Peksen, Dursun (2019) "Autocracies and Economic Sanctions: The Divergent Impact of Authoritarian Regime Type on Sanctions Success," Defense and Peace Economics 30(3):253-68.

Rose, Andrew (2004) "Do We Really Know That The WTO Increases Trade?" American Economic Review 94(1): 98-114.

Santos Silva, J. and Silvana Tenreyro (2006) “The Log of Gravity," The Review of Economics and Statistics 88(4): 641-658.

Schweller, Randall (2011) "The future is uncertain and the end is always near," Cambridge Review of International Affairs 24(2):175-184.

Simon, Steven and Jonathan Stevenson (2019) "Iran: The Case Against War," New York Review of Books 66(13):24-26.

Singer, J. David (1987) "Reconstructing the Correlates of War Dataset on Material Capabilities of States, 1816-1985" International Interactions 14:115-32. (Version 5.0 at http://www.correlatesofwar.org/data-sets/national-material-capabilities).

Singer, J. David, Stuart Bremer, and John Stuckey (1972) "Capability Distribution, Uncertainty, and Major Power War, 1820-1965,' in Peace, War, and Numbers, Bruce Russet (ed.), 19-48. Beverly Hills, CA: SAGE.

Slovov, Slavi (2007) "Innocent or Not-So-Innocent Bystanders: Evidence from the Gravity Model of International Trade about the Effects of UN Sanctions on Neighbour Countries," The World Economy 30(11):1701-1725.

de Sousa, José (2012), "The currency union effect on trade is decreasing over time," Economics Letters 117(3):917-920.

Yang, Jiawen, Hossein Askari, John Forrer, and Hildy Teegen (2004) "U.S. Economic Sanctions: An Empirical Study," The International Trade Journal 28 (1): 23-62.

Yang, Jiawen, Hossein Askari, John Forrer, and Lili Zhu (2009) "How Do US Economic Sanctions Affect EU's Trade with Target Countries?" The World Economy 32(8):12231244. 
Appendix

\begin{tabular}{|c|c|c|c|c|c|c|}
\hline & \multicolumn{2}{|c|}{ Total bilateral trade } & \multicolumn{2}{|c|}{$\begin{array}{c}3^{\text {rd }} \text { state imports } \\
\text { from target }\end{array}$} & \multicolumn{2}{|c|}{$\begin{array}{c}3^{\text {rd }} \text { state exports } \\
\text { to target }\end{array}$} \\
\hline & 1950-1991 & $1992-2006$ & 1950-1991 & $1992-2006$ & 1950-1991 & $1992-2006$ \\
\hline \multirow[t]{2}{*}{ RTA } & $0.531 * *$ & 0.116 & $0.473 * *$ & 0.113 & $0.588 * *$ & $0.113^{*}$ \\
\hline & $(0.0937)$ & $(0.0657)$ & $(0.0983)$ & $(0.0868)$ & $(0.0950)$ & $(0.0576)$ \\
\hline \multirow[t]{2}{*}{ Common currency } & -0.315 & $-0.0701 * *$ & -0.320 & -0.0251 & -0.312 & $-0.131 * *$ \\
\hline & $(0.235)$ & $(0.0265)$ & $(0.258)$ & $(0.0351)$ & $(0.226)$ & $(0.0365)$ \\
\hline \multirow[t]{2}{*}{ MID } & -0.0715 & 0.0462 & 0.0187 & 0.0582 & $-0.166 * *$ & 0.0319 \\
\hline & $(0.0523)$ & $(0.0356)$ & $(0.0644)$ & $(0.0452)$ & $(0.0589)$ & $(0.0264)$ \\
\hline \multirow[t]{2}{*}{ Sanction } & 0.160 & $-0.310 * *$ & 0.149 & $-0.397 * *$ & 0.163 & $-0.227 * *$ \\
\hline & $(0.0820)$ & $(0.0654)$ & $(0.0994)$ & $(0.0891)$ & $(0.0960)$ & $(0.0836)$ \\
\hline \multirow[t]{2}{*}{ Defense } & $0.297 * *$ & $0.160 * *$ & $0.342 * *$ & 0.0949 & $0.258 *$ & $0.241 * *$ \\
\hline & $(0.0935)$ & $(0.0543)$ & $(0.0904)$ & $(0.0630)$ & $(0.115)$ & $(0.0612)$ \\
\hline \multirow[t]{2}{*}{ DefenseUS } & 0.215 & $0.252 * *$ & $0.292 *$ & $0.269 * *$ & 0.0831 & 0.205 \\
\hline & $(0.124)$ & $(0.0918)$ & $(0.140)$ & $(0.104)$ & $(0.126)$ & $(0.112)$ \\
\hline \multirow[t]{2}{*}{ Tradeshare } & $3.847 * *$ & $3.403 * *$ & $3.645 * *$ & $3.384 * *$ & $4.030 * *$ & $3.431 * *$ \\
\hline & $(0.519)$ & $(0.747)$ & $(0.599)$ & $(0.926)$ & $(0.587)$ & $(0.670)$ \\
\hline \multirow[t]{2}{*}{ PowerUS } & $-0.631 * *$ & 0.0569 & $-0.583^{* *}$ & 0.140 & $-0.683 * *$ & -0.0291 \\
\hline & $(0.0872)$ & $(0.101)$ & $(0.0946)$ & $(0.118)$ & $(0.0953)$ & $(0.104)$ \\
\hline \multirow[t]{2}{*}{ Democracy } & -0.0200 & $-0.129 * *$ & -0.0481 & $-0.153^{* *}$ & 0.00614 & -0.0980 \\
\hline & $(0.0430)$ & $(0.0363)$ & $(0.0519)$ & $(0.0341)$ & $(0.0493)$ & $(0.0580)$ \\
\hline \multirow[t]{2}{*}{ Defense*Sanction } & -0.0966 & -0.118 & -0.133 & -0.0384 & -0.0632 & $-0.235^{*}$ \\
\hline & $(0.0698)$ & $(0.113)$ & $(0.0704)$ & $(0.149)$ & $(0.0872)$ & $(0.110)$ \\
\hline \multirow[t]{2}{*}{ DefenseUS*Sanction } & -0.0585 & $0.155^{*}$ & -0.0730 & 0.0763 & -0.0350 & $0.302 * *$ \\
\hline & $(0.0591)$ & $(0.0627)$ & $(0.0748)$ & $(0.0768)$ & $(0.0705)$ & $(0.0741)$ \\
\hline \multirow[t]{2}{*}{ PowerUS*Sanction } & $9.79 \mathrm{e}-05$ & $0.0429 *$ & -0.0167 & 0.0342 & 0.0152 & $0.0550 *$ \\
\hline & $(0.0190)$ & $(0.0175)$ & $(0.0227)$ & $(0.0223)$ & $(0.0230)$ & $(0.0223)$ \\
\hline \multirow[t]{2}{*}{ Democracy*Sanction } & $-0.221 * *$ & $-0.135^{*}$ & $-0.137 *$ & -0.0117 & $-0.303 * *$ & $-0.277 * *$ \\
\hline & $(0.0555)$ & $(0.0575)$ & $(0.0544)$ & $(0.0700)$ & $(0.0778)$ & $(0.0697)$ \\
\hline \multirow[t]{2}{*}{ Tradeshare*Sanction } & 0.0768 & 0.170 & 0.0748 & -0.143 & 0.136 & 0.527 \\
\hline & $(0.621)$ & $(0.731)$ & $(0.649)$ & $(0.776)$ & $(0.693)$ & $(0.803)$ \\
\hline \multirow[t]{2}{*}{ DefenseUS*Tradeshare } & 0.597 & 0.251 & 0.653 & 0.397 & 0.634 & 0.0944 \\
\hline & $(0.805)$ & $(0.515)$ & $(0.889)$ & $(0.617)$ & $(0.825)$ & $(0.527)$ \\
\hline \multirow[t]{2}{*}{ DefenseUS*Sanction*Tradeshare } & -0.182 & 0.867 & 0.285 & -0.147 & -0.770 & 1.652 \\
\hline & $(1.137)$ & (1.154) & $(1.116)$ & $(1.473)$ & $(1.261)$ & $(1.103)$ \\
\hline \multirow[t]{2}{*}{ MID*Sanction } & -0.0264 & -0.0453 & $-0.197 *$ & -0.0724 & 0.147 & -0.0178 \\
\hline & $(0.0812)$ & $(0.0504)$ & $(0.0964)$ & $(0.0518)$ & $(0.0972)$ & $(0.0518)$ \\
\hline Observations & 239,566 & 143,778 & 231,685 & 139,394 & 228,409 & 138,222 \\
\hline Dyads & 8,024 & 10,149 & 7,630 & 9,782 & 7,442 & 9,695 \\
\hline
\end{tabular}

Table A1 Fixed effects Poisson models of target-third-state dyadic trade, including extra controls for regional trade agreements and common currencies

$* * p<0.01, * p<0.05$. Estimated coefficients with robust standard errors clustered by dyad in parentheses. Controls for real GDP and population size included but not reported. 


\begin{tabular}{|c|c|c|c|c|c|c|}
\hline & \multicolumn{2}{|c|}{ "Total bilateral trade } & \multicolumn{2}{|c|}{$\begin{array}{l}3^{\text {rd }} \text { state imports } \\
\text { from target }\end{array}$} & \multicolumn{2}{|c|}{$\begin{array}{c}3^{\text {rd }} \text { state exports } \\
\text { to target }\end{array}$} \\
\hline & 1950-1991 & $1992-2006$ & $1950-1991$ & $1992-2006$ & 1950-1991 & $1992-2006$ \\
\hline \multirow[t]{2}{*}{ MID } & -0.0774 & 0.0476 & 0.00553 & 0.0589 & $-0.164 * *$ & 0.0346 \\
\hline & $(0.0486)$ & $(0.0354)$ & $(0.0605)$ & $(0.0445)$ & $(0.0555)$ & $(0.0275)$ \\
\hline \multirow[t]{2}{*}{ Sanction } & $0.196 * *$ & $-0.339 * *$ & $0.187^{*}$ & $-0.418 * *$ & $0.197 *$ & $-0.278 * *$ \\
\hline & $(0.0754)$ & $(0.0626)$ & $(0.0953)$ & $(0.0831)$ & $(0.0874)$ & $(0.0850)$ \\
\hline \multirow[t]{2}{*}{ Defense } & $0.306^{* *}$ & $0.151 * *$ & $0.333 * *$ & 0.0899 & $0.278 * *$ & $0.225^{* *}$ \\
\hline & $(0.0865)$ & $(0.0573)$ & $(0.0879)$ & $(0.0637)$ & $(0.105)$ & $(0.0647)$ \\
\hline \multirow[t]{2}{*}{ DefenseUS } & 0.234 & $0.212 *$ & $0.294 *$ & $0.246^{*}$ & 0.130 & 0.101 \\
\hline & $(0.121)$ & $(0.0925)$ & $(0.138)$ & $(0.104)$ & $(0.121)$ & $(0.112)$ \\
\hline \multirow[t]{2}{*}{ Tradeshare } & $3.805 * *$ & $3.559 * *$ & $3.470 * *$ & $3.439 * *$ & $4.130 * *$ & $3.816^{* *}$ \\
\hline & $(0.536)$ & $(0.727)$ & $(0.647)$ & $(0.883)$ & $(0.545)$ & $(0.682)$ \\
\hline \multirow[t]{2}{*}{ PowerUS } & $-0.610 * *$ & -0.0266 & $-0.585 * *$ & 0.0582 & $-0.637 * *$ & -0.122 \\
\hline & $(0.0693)$ & (0.0997) & $(0.0782)$ & $(0.118)$ & $(0.0781)$ & $(0.102)$ \\
\hline \multirow[t]{2}{*}{ Democracy } & -0.0276 & $-0.116 * *$ & -0.0521 & $-0.143 * *$ & -0.00550 & -0.0767 \\
\hline & $(0.0389)$ & $(0.0370)$ & $(0.0483)$ & $(0.0343)$ & $(0.0450)$ & $(0.0595)$ \\
\hline \multirow[t]{2}{*}{ Defense*Sanction } & $-0.138 *$ & -0.126 & $-0.178 * *$ & -0.0516 & -0.0984 & $-0.240 *$ \\
\hline & $(0.0585)$ & $(0.111)$ & $(0.0635)$ & $(0.148)$ & $(0.0732)$ & $(0.106)$ \\
\hline \multirow[t]{2}{*}{ DefenseUS*Sanction } & -0.0982 & $0.161 * *$ & -0.112 & 0.0821 & -0.0761 & $0.305^{* *}$ \\
\hline & $(0.0571)$ & $(0.0615)$ & $(0.0732)$ & $(0.0746)$ & $(0.0669)$ & $(0.0741)$ \\
\hline \multirow[t]{2}{*}{ PowerUS*Sanction } & -0.0283 & $0.0518 * *$ & $-0.0460 *$ & $0.0419 *$ & -0.0119 & $0.0693 * *$ \\
\hline & $(0.0184)$ & $(0.0169)$ & $(0.0227)$ & $(0.0214)$ & $(0.0222)$ & $(0.0224)$ \\
\hline \multirow[t]{2}{*}{ Democracy*Sanction } & $-0.179 * *$ & $-0.140 *$ & $-0.130 *$ & -0.0188 & $-0.228 * *$ & $-0.271 * *$ \\
\hline & $(0.0449)$ & $(0.0572)$ & $(0.0528)$ & $(0.0705)$ & $(0.0621)$ & $(0.0697)$ \\
\hline \multirow[t]{2}{*}{ Tradeshare*Sanction } & 0.133 & 0.227 & 0.272 & -0.0499 & 0.0261 & 0.475 \\
\hline & $(0.501)$ & $(0.738)$ & $(0.565)$ & $(0.768)$ & $(0.550)$ & $(0.841)$ \\
\hline \multirow[t]{2}{*}{ DefenseUS*Tradeshare } & 1.118 & 0.451 & 1.252 & 0.502 & 1.037 & 0.474 \\
\hline & $(0.866)$ & $(0.526)$ & $(0.962)$ & $(0.619)$ & $(0.882)$ & $(0.538)$ \\
\hline \multirow[t]{2}{*}{ DefenseUS*Sanction*Tradeshare } & $1.647^{*}$ & 0.825 & $2.029 *$ & -0.182 & 1.203 & 1.522 \\
\hline & $(0.774)$ & (1.210) & $(0.920)$ & (1.509) & $(0.802)$ & (1.166) \\
\hline \multirow[t]{2}{*}{ MID*Sanction } & -0.0219 & -0.0439 & $-0.193 *$ & -0.0712 & 0.154 & -0.0115 \\
\hline & $(0.0830)$ & $(0.0501)$ & $(0.0971)$ & $(0.0505)$ & $(0.0979)$ & $(0.0514)$ \\
\hline \multirow[t]{2}{*}{ Trade openess } & $0.0168 * *$ & $0.00208 * *$ & $0.0155^{* *}$ & $0.00171 * *$ & $0.0181 * *$ & $0.00418 * *$ \\
\hline & (0.00199) & $(0.000440)$ & $(0.00206)$ & $(0.000329)$ & $(0.00209)$ & $(0.00122)$ \\
\hline Observations & 243,327 & 143,778 & 235,212 & 139,394 & 231,880 & 138,222 \\
\hline Dyads & 8,257 & 10,149 & 7,852 & 9,782 & 7,663 & 9,695 \\
\hline
\end{tabular}

Table A2 Fixed effects Poisson models of target-third-state dyadic trade, including extra control for trade openness of third-state

${ }^{*} \mathrm{p}<0.01, * \mathrm{p}<0.05$. Estimated coefficients with robust standard errors clustered by dyad in parentheses. Controls for real GDP and population size included but not reported. 


\begin{tabular}{|c|c|c|c|c|c|c|}
\hline & \multicolumn{2}{|c|}{ Total bilateral trade } & \multicolumn{2}{|c|}{$\begin{array}{l}3^{\text {rd }} \text { state imports } \\
\text { from target }\end{array}$} & \multicolumn{2}{|c|}{$\begin{array}{c}3^{\text {rd }} \text { state exports } \\
\text { to target }\end{array}$} \\
\hline & 1950-1991 & $1992-2006$ & 1950-1991 & $1992-2006$ & 1950-1991 & $1992-2006$ \\
\hline \multirow[t]{2}{*}{ MID } & -0.0434 & 0.0463 & 0.0430 & 0.0577 & $-0.135^{*}$ & 0.0309 \\
\hline & $(0.0542)$ & $(0.0342)$ & $(0.0637)$ & $(0.0436)$ & $(0.0610)$ & $(0.0245)$ \\
\hline \multirow[t]{2}{*}{ Sanction } & $0.212 * *$ & $-0.334 * *$ & $0.200 *$ & $-0.420 * *$ & $0.216^{*}$ & $-0.272 * *$ \\
\hline & $(0.0790)$ & $(0.0635)$ & $(0.0945)$ & $(0.0839)$ & $(0.0944)$ & $(0.0889)$ \\
\hline \multirow[t]{2}{*}{ Defense } & $0.263 * *$ & $0.151 *$ & $0.276 * *$ & 0.0879 & $0.253^{*}$ & $0.225 * *$ \\
\hline & $(0.0907)$ & $(0.0592)$ & $(0.0913)$ & $(0.0647)$ & $(0.112)$ & $(0.0729)$ \\
\hline \multirow[t]{2}{*}{ DefenseUS } & $0.520 * *$ & $0.213^{*}$ & $0.609 * *$ & $0.243^{*}$ & $0.385^{* *}$ & 0.0520 \\
\hline & $(0.118)$ & $(0.0918)$ & $(0.131)$ & $(0.103)$ & $(0.126)$ & $(0.113)$ \\
\hline \multirow[t]{2}{*}{ Tradeshare } & $3.192 * *$ & $3.226 * *$ & $2.813 * *$ & $3.067 * *$ & $3.544 * *$ & $3.220 * *$ \\
\hline & $(0.435)$ & $(0.699)$ & $(0.578)$ & $(0.849)$ & $(0.442)$ & $(0.642)$ \\
\hline \multirow[t]{2}{*}{ PowerUS } & $-0.548 * *$ & -0.0243 & $-0.520 * *$ & 0.0665 & $-0.585 * *$ & -0.171 \\
\hline & $(0.0737)$ & $(0.0998)$ & $(0.0815)$ & $(0.117)$ & $(0.0806)$ & $(0.104)$ \\
\hline \multirow[t]{2}{*}{ Democracy } & -0.00633 & $-0.119 * *$ & -0.0302 & $-0.146^{* *}$ & 0.0161 & -0.0750 \\
\hline & $(0.0487)$ & $(0.0365)$ & $(0.0619)$ & $(0.0343)$ & $(0.0490)$ & $(0.0579)$ \\
\hline \multirow[t]{2}{*}{ Defense*Sanction } & $-0.187 * *$ & -0.0985 & $-0.229 * *$ & -0.0443 & -0.147 & -0.132 \\
\hline & $(0.0637)$ & $(0.108)$ & $(0.0656)$ & $(0.149)$ & $(0.0808)$ & $(0.0946)$ \\
\hline \multirow[t]{2}{*}{ DefenseUS*Sanction } & $-0.114 *$ & $0.152^{*}$ & -0.134 & 0.0835 & -0.0870 & $0.247 * *$ \\
\hline & $(0.0576)$ & $(0.0633)$ & $(0.0726)$ & $(0.0761)$ & $(0.0690)$ & $(0.0747)$ \\
\hline \multirow[t]{2}{*}{ PowerUS*Sanction } & -0.00406 & $0.0515 * *$ & -0.0189 & 0.0409 & 0.00964 & $0.0797 * *$ \\
\hline & $(0.0186)$ & $(0.0171)$ & $(0.0216)$ & $(0.0215)$ & $(0.0234)$ & $(0.0228)$ \\
\hline \multirow[t]{2}{*}{ Democracy*Sanction } & $-0.249 * *$ & $-0.141 *$ & $-0.169 * *$ & -0.0221 & $-0.326 * *$ & $-0.261 * *$ \\
\hline & $(0.0559)$ & $(0.0565)$ & $(0.0562)$ & $(0.0707)$ & $(0.0773)$ & $(0.0672)$ \\
\hline \multirow[t]{2}{*}{ Tradeshare*Sanction } & 0.0467 & -0.0321 & 0.214 & -0.103 & -0.0775 & -1.443 \\
\hline & $(0.529)$ & $(0.792)$ & $(0.591)$ & $(0.791)$ & $(0.592)$ & $(1.103)$ \\
\hline \multirow[t]{2}{*}{ DefenseUS*Tradeshare } & -1.164 & 0.439 & -1.002 & 0.554 & -1.293 & 0.275 \\
\hline & $(0.838)$ & $(0.525)$ & $(0.889)$ & $(0.614)$ & $(0.886)$ & $(0.545)$ \\
\hline \multirow[t]{2}{*}{ DefenseUS*Sanction*Tradeshare } & 1.514 & 1.032 & 1.877 & -0.0833 & 1.097 & 2.702 \\
\hline & (1.014) & (1.230) & (1.000) & $(1.520)$ & (1.149) & $(1.428)$ \\
\hline \multirow[t]{2}{*}{ MID*Sanction } & -0.0471 & -0.0406 & $-0.219 *$ & -0.0706 & 0.128 & 0.0196 \\
\hline & $(0.0811)$ & $(0.0502)$ & $(0.0951)$ & $(0.0500)$ & $(0.0975)$ & $(0.0539)$ \\
\hline \multirow[t]{2}{*}{ Reliance3T } & $9.639 * *$ & $0.995^{*}$ & $10.06 * *$ & $0.703^{*}$ & $9.285^{* *}$ & $4.152 * *$ \\
\hline & $(2.276)$ & $(0.441)$ & $(2.037)$ & $(0.285)$ & $(2.771)$ & $(0.449)$ \\
\hline Observations & 245,726 & 143,778 & 237,048 & 139,373 & 233,787 & 138,205 \\
\hline Dyads & 8,299 & 10,149 & 7,884 & 9,781 & 7,696 & 9,695 \\
\hline
\end{tabular}

Table A3 Fixed effects Poisson models of target-third-state dyadic trade, including extra control for third state economic reliance on the target state

$* * p<0.01, * p<0.05$. Estimated coefficients with robust standard errors clustered by dyad in parentheses. Controls for real GDP and population size included but not reported. 


\begin{tabular}{|c|c|c|c|c|c|c|}
\hline & \multicolumn{2}{|c|}{ Total bilateral trade } & \multicolumn{2}{|c|}{$\begin{array}{l}3^{\text {rd }} \text { state imports } \\
\text { from target }\end{array}$} & \multicolumn{2}{|c|}{$\begin{array}{c}3^{\text {rd }} \text { state exports } \\
\text { to target }\end{array}$} \\
\hline & 1950-1991 & $1992-2006$ & 1950-1991 & $1992-2006$ & 1950-1991 & $1992-2006$ \\
\hline \multirow[t]{2}{*}{ MID } & -0.0541 & 0.0472 & 0.0349 & 0.0588 & $-0.146^{*}$ & 0.0335 \\
\hline & $(0.0559)$ & $(0.0354)$ & $(0.0681)$ & $(0.0446)$ & $(0.0623)$ & $(0.0266)$ \\
\hline \multirow[t]{2}{*}{ Sanction } & 0.121 & $-0.293 * *$ & 0.112 & $-0.385 * *$ & 0.125 & $-0.209 * *$ \\
\hline & $(0.0850)$ & $(0.0597)$ & $(0.104)$ & $(0.0798)$ & $(0.101)$ & $(0.0783)$ \\
\hline \multirow[t]{2}{*}{ Defense } & $0.372 * *$ & $0.156 * *$ & $0.405 * *$ & 0.0927 & $0.344 * *$ & $0.237 * *$ \\
\hline & $(0.0812)$ & $(0.0567)$ & $(0.0806)$ & $(0.0636)$ & $(0.103)$ & $(0.0642)$ \\
\hline \multirow[t]{2}{*}{ DefenseUS } & $0.428 * *$ & $0.236 *$ & $0.495 * *$ & $0.261 *$ & $0.319 *$ & 0.162 \\
\hline & $(0.130)$ & $(0.0938)$ & $(0.144)$ & $(0.104)$ & $(0.135)$ & $(0.114)$ \\
\hline \multirow[t]{2}{*}{ Tradeshare } & $2.953 * *$ & $3.505 * *$ & $2.516 * *$ & $3.442 * *$ & $3.344 * *$ & $3.596 * *$ \\
\hline & $(0.668)$ & $(0.740)$ & $(0.733)$ & $(0.905)$ & $(0.693)$ & $(0.675)$ \\
\hline \multirow[t]{2}{*}{ PowerUS } & $-0.661 * *$ & 0.0285 & $-0.605 * *$ & 0.123 & $-0.715 * *$ & -0.0690 \\
\hline & $(0.0873)$ & $(0.103)$ & $(0.0966)$ & $(0.121)$ & (0.0939) & $(0.105)$ \\
\hline \multirow[t]{2}{*}{ Democracy } & -0.0387 & $-0.115^{* *}$ & -0.0680 & $-0.139 * *$ & -0.0116 & -0.0854 \\
\hline & $(0.0468)$ & $(0.0374)$ & $(0.0565)$ & $(0.0351)$ & $(0.0508)$ & $(0.0593)$ \\
\hline \multirow[t]{2}{*}{ Defense*Sanction } & $-0.230 * *$ & -0.119 & $-0.270 * *$ & -0.0515 & $-0.194 *$ & $-0.222 *$ \\
\hline & $(0.0667)$ & $(0.114)$ & $(0.0672)$ & $(0.152)$ & $(0.0842)$ & $(0.107)$ \\
\hline \multirow[t]{2}{*}{ DefenseUS*Sanction } & -0.0977 & $0.185^{* *}$ & -0.119 & 0.119 & -0.0679 & $0.312 * *$ \\
\hline & $(0.0616)$ & $(0.0605)$ & $(0.0761)$ & $(0.0745)$ & $(0.0727)$ & $(0.0719)$ \\
\hline \multirow[t]{2}{*}{ PowerUS*Sanction } & 0.00181 & $0.0477 * *$ & -0.0157 & 0.0394 & 0.0178 & $0.0592 * *$ \\
\hline & $(0.0194)$ & $(0.0167)$ & $(0.0234)$ & $(0.0206)$ & $(0.0234)$ & $(0.0219)$ \\
\hline \multirow[t]{2}{*}{ Democracy*Sanction } & $-0.207 * *$ & $-0.191 * *$ & $-0.124 *$ & -0.0719 & $-0.291 * *$ & $-0.321 * *$ \\
\hline & $(0.0575)$ & $(0.0608)$ & $(0.0581)$ & $(0.0776)$ & $(0.0794)$ & $(0.0703)$ \\
\hline \multirow[t]{2}{*}{ Tradeshare*Sanction } & 0.583 & 0.237 & 0.812 & -0.0407 & 0.424 & 0.573 \\
\hline & $(0.573)$ & $(0.758)$ & $(0.604)$ & $(0.786)$ & $(0.628)$ & $(0.835)$ \\
\hline \multirow[t]{2}{*}{ DefenseUS*Tradeshare } & -0.887 & 0.418 & -0.712 & 0.472 & -1.010 & 0.410 \\
\hline & $(0.979)$ & $(0.536)$ & $(0.999)$ & $(0.630)$ & $(1.037)$ & $(0.548)$ \\
\hline \multirow[t]{2}{*}{ DefenseUS*Sanction*Tradeshare } & 1.306 & 0.811 & 1.648 & -0.256 & 0.881 & 1.537 \\
\hline & $(1.066)$ & $(1.229)$ & $(1.044)$ & $(1.525)$ & $(1.188)$ & $(1.165)$ \\
\hline \multirow[t]{2}{*}{ MID*Sanction } & -0.0511 & -0.0477 & $-0.227 *$ & -0.0749 & 0.127 & -0.0204 \\
\hline & $(0.0884)$ & $(0.0501)$ & $(0.104)$ & $(0.0508)$ & $(0.103)$ & $(0.0508)$ \\
\hline \multirow[t]{2}{*}{ Comprehensive sanctions (FXM) } & $0.174 * *$ & $-0.330 * *$ & $0.182 * *$ & $-0.303 * *$ & $0.168 *$ & $-0.320 *$ \\
\hline & $(0.0609)$ & $(0.0935)$ & $(0.0677)$ & $(0.0938)$ & $(0.0715)$ & $(0.142)$ \\
\hline Observations & 245,726 & 143,778 & 237,628 & 139,394 & 234,295 & 138,222 \\
\hline Dyads & 8,299 & 10,149 & 7,893 & 9,782 & 7,702 & 9,695 \\
\hline
\end{tabular}

Table A4 Fixed effects Poisson models of target-third-state dyadic trade, including extra control for comprehensiveness of sanctions

$*^{*} \mathrm{p}<0.01, * \mathrm{p}<0.05$. Estimated coefficients with robust standard errors clustered by dyad in parentheses. Controls for real GDP and population size included but not reported. 


\begin{tabular}{|c|c|c|c|c|c|c|}
\hline & \multicolumn{2}{|c|}{ Total bilateral trade } & \multicolumn{2}{|c|}{$\begin{array}{c}3^{\text {rd }} \text { state imports } \\
\text { from target }\end{array}$} & \multicolumn{2}{|c|}{$\begin{array}{c}3^{\text {rd }} \text { state exports } \\
\text { to target }\end{array}$} \\
\hline & $1950-1991$ & $1992-2006$ & $1950-1991$ & $1992-2006$ & 1950-1991 & 1992-2006 \\
\hline \multirow[t]{2}{*}{ MID } & -0.0506 & 0.0445 & 0.0383 & 0.0555 & $-0.143^{*}$ & 0.0323 \\
\hline & $(0.0553)$ & $(0.0355)$ & $(0.0671)$ & $(0.0448)$ & $(0.0623)$ & $(0.0265)$ \\
\hline \multirow[t]{2}{*}{ Sanction } & $0.180 *$ & $-0.223 * *$ & 0.177 & $-0.296 * *$ & 0.177 & $-0.174 *$ \\
\hline & $(0.0866)$ & $(0.0646)$ & $(0.104)$ & $(0.0839)$ & $(0.101)$ & $(0.0847)$ \\
\hline \multirow[t]{2}{*}{ Defense } & $0.358 * *$ & $0.148 *$ & $0.387 * *$ & 0.0816 & $0.334 * *$ & $0.232 * *$ \\
\hline & $(0.0839)$ & $(0.0595)$ & $(0.0836)$ & $(0.0667)$ & $(0.105)$ & $(0.0659)$ \\
\hline \multirow[t]{2}{*}{ DefenseUS } & $0.430 * *$ & $0.223^{*}$ & $0.500 * *$ & $0.252 *$ & $0.317^{*}$ & 0.151 \\
\hline & $(0.131)$ & $(0.0935)$ & $(0.146)$ & $(0.104)$ & $(0.136)$ & $(0.115)$ \\
\hline \multirow[t]{2}{*}{ Tradeshare } & $2.910 * *$ & $3.462 * *$ & $2.477 * *$ & $3.416 * *$ & $3.300 * *$ & $3.555 * *$ \\
\hline & $(0.658)$ & $(0.750)$ & $(0.722)$ & $(0.922)$ & $(0.684)$ & $(0.680)$ \\
\hline \multirow[t]{2}{*}{ PowerUS } & $-0.647 * *$ & 0.0275 & $-0.588 * *$ & 0.123 & $-0.705 * *$ & -0.0707 \\
\hline & $(0.0871)$ & $(0.102)$ & $(0.0964)$ & $(0.120)$ & $(0.0936)$ & $(0.104)$ \\
\hline \multirow{2}{*}{ Democracy } & -0.0318 & $-0.110 * *$ & -0.0606 & $-0.130 * *$ & -0.00471 & -0.0843 \\
\hline & $(0.0475)$ & $(0.0366)$ & $(0.0571)$ & $(0.0334)$ & $(0.0513)$ & $(0.0591)$ \\
\hline \multirow[t]{2}{*}{ Defense*Sanction } & $-0.220 * *$ & -0.166 & $-0.262 * *$ & -0.109 & $-0.181 *$ & $-0.256^{*}$ \\
\hline & $(0.0673)$ & $(0.109)$ & $(0.0682)$ & $(0.142)$ & $(0.0845)$ & $(0.108)$ \\
\hline \multirow[t]{2}{*}{ DefenseUS*Sanction } & -0.0968 & $0.167 * *$ & -0.118 & 0.0916 & -0.0673 & $0.310 * *$ \\
\hline & $(0.0624)$ & $(0.0593)$ & $(0.0766)$ & $(0.0703)$ & $(0.0734)$ & $(0.0730)$ \\
\hline \multirow[t]{2}{*}{ PowerUS*Sanction } & -0.00128 & $0.0484 * *$ & -0.0184 & $0.0413 *$ & 0.0143 & $0.0594 * *$ \\
\hline & $(0.0198)$ & $(0.0160)$ & $(0.0232)$ & $(0.0190)$ & $(0.0241)$ & $(0.0223)$ \\
\hline \multirow[t]{2}{*}{ Democracy*Sanction } & $-0.228 * *$ & $-0.106^{*}$ & $-0.145^{*}$ & 0.0323 & $-0.314 * *$ & $-0.270 * *$ \\
\hline & $(0.0629)$ & $(0.0510)$ & $(0.0640)$ & $(0.0588)$ & $(0.0814)$ & $(0.0681)$ \\
\hline \multirow[t]{2}{*}{ Tradeshare*Sanction } & 0.627 & 0.742 & 0.855 & 0.556 & 0.470 & 0.922 \\
\hline & $(0.561)$ & $(0.778)$ & $(0.590)$ & $(0.784)$ & $(0.617)$ & $(0.862)$ \\
\hline \multirow[t]{2}{*}{ DefenseUS*Tradeshare } & -0.859 & 0.480 & -0.695 & 0.526 & -0.970 & 0.465 \\
\hline & $(0.977)$ & $(0.544)$ & $(0.999)$ & $(0.642)$ & $(1.035)$ & $(0.552)$ \\
\hline \multirow[t]{2}{*}{ DefenseUS*Sanction*Tradeshare } & 1.238 & 0.879 & 1.591 & -0.164 & 0.804 & 1.564 \\
\hline & $(1.052)$ & $(1.267)$ & $(1.028)$ & $(1.586)$ & $(1.184)$ & $(1.187)$ \\
\hline \multirow[t]{2}{*}{ MID*Sanction } & -0.0315 & -0.0405 & $-0.203 *$ & -0.0611 & 0.143 & -0.0194 \\
\hline & $(0.0826)$ & $(0.0490)$ & $(0.0983)$ & $(0.0506)$ & $(0.0991)$ & $(0.0505)$ \\
\hline \multirow[t]{2}{*}{ Timeundersanction } & -0.0024 & $-0.0083 * *$ & -0.0030 & $-0.0095 * *$ & -0.00140 & $-0.00578 *$ \\
\hline & $(0.00373)$ & $(0.00193)$ & $(0.00455)$ & $(0.00217)$ & $(0.00352)$ & $(0.00227)$ \\
\hline Observations & 245,726 & 143,778 & 237,628 & 139,394 & 234,295 & 138,222 \\
\hline Dyads & 8,299 & 10,149 & 7,893 & 9,782 & 7,702 & 9,695 \\
\hline
\end{tabular}

Table A5 Fixed effects Poisson models of target-third-state dyadic trade, including extra control for time under sanctions

$* * \mathrm{p}<0.01, * \mathrm{p}<0.05$. Estimated coefficients with robust standard errors clustered by dyad in parentheses. Controls for real GDP and population size included but not reported. 


\begin{tabular}{|c|c|c|c|c|c|c|}
\hline & \multicolumn{2}{|c|}{ "Total bilateral trade } & \multicolumn{2}{|c|}{$\begin{array}{c}3^{\text {rd }} \text { state imports } \\
\text { from target }\end{array}$} & \multicolumn{2}{|c|}{$\begin{array}{c}3^{\text {rd }} \text { state exports } \\
\text { to target }\end{array}$} \\
\hline & 1950-1991 & $1992-2006$ & 1950-1991 & $1992-2006$ & $1950-1991$ & 1992-2006 \\
\hline \multirow[t]{2}{*}{ MID } & -0.102 & 0.0417 & -0.0286 & 0.0615 & $-0.180 * *$ & 0.0174 \\
\hline & $(0.0682)$ & $(0.0407)$ & $(0.0902)$ & $(0.0476)$ & $(0.0570)$ & $(0.0340)$ \\
\hline \multirow[t]{2}{*}{ Sanction } & 0.0724 & $-0.291 * *$ & 0.0583 & $-0.341 * *$ & 0.0809 & $-0.250 * *$ \\
\hline & $(0.0653)$ & $(0.0665)$ & $(0.0836)$ & $(0.0865)$ & $(0.0797)$ & $(0.0864)$ \\
\hline \multirow[t]{2}{*}{ Defense } & $0.540 * *$ & 0.120 & $0.557 * *$ & 0.0465 & $0.524 * *$ & $0.210 * *$ \\
\hline & $(0.0811)$ & $(0.0719)$ & $(0.0833)$ & $(0.0790)$ & $(0.0905)$ & $(0.0765)$ \\
\hline \multirow[t]{2}{*}{ DefenseUS } & 0.161 & $0.234 * *$ & $0.241 *$ & $0.268 * *$ & 0.0436 & 0.153 \\
\hline & $(0.108)$ & $(0.0865)$ & $(0.120)$ & $(0.0973)$ & $(0.112)$ & $(0.111)$ \\
\hline \multirow[t]{2}{*}{ Tradeshare } & $4.229 * *$ & $4.384 * *$ & $3.897 * *$ & $4.294 * *$ & $4.550 * *$ & $4.520 * *$ \\
\hline & $(0.492)$ & $(0.586)$ & $(0.505)$ & $(0.754)$ & $(0.560)$ & $(0.523)$ \\
\hline \multirow[t]{2}{*}{ PowerUS } & $-0.380 * *$ & $-0.667 * *$ & $-0.399 * *$ & $-0.575^{* *}$ & $-0.370 * *$ & $-0.751 * *$ \\
\hline & $(0.0605)$ & $(0.123)$ & $(0.0737)$ & $(0.156)$ & $(0.0667)$ & $(0.115)$ \\
\hline \multirow[t]{2}{*}{ Democracy } & 0.000746 & $-0.0855 * *$ & -0.0321 & $-0.108 * *$ & 0.0315 & -0.0562 \\
\hline & $(0.0268)$ & $(0.0298)$ & $(0.0343)$ & $(0.0293)$ & $(0.0357)$ & $(0.0504)$ \\
\hline \multirow[t]{2}{*}{ Defense*Sanction } & -0.0223 & -0.0956 & -0.0520 & -0.0289 & 0.00328 & -0.190 \\
\hline & $(0.0573)$ & $(0.0867)$ & $(0.0591)$ & $(0.114)$ & $(0.0711)$ & $(0.0994)$ \\
\hline \multirow[t]{2}{*}{ DefenseUS*sanction } & $-0.106^{*}$ & $0.189 * *$ & -0.131 & 0.114 & -0.0702 & $0.319 * *$ \\
\hline & $(0.0526)$ & $(0.0547)$ & $(0.0696)$ & $(0.0668)$ & $(0.0606)$ & $(0.0708)$ \\
\hline \multirow[t]{2}{*}{ PowerUS*Sanction } & -0.0120 & $0.0446^{*}$ & -0.0266 & 0.0314 & 0.00132 & $0.0622 * *$ \\
\hline & $(0.0145)$ & $(0.0177)$ & $(0.0194)$ & $(0.0225)$ & $(0.0180)$ & $(0.0223)$ \\
\hline \multirow{2}{*}{ Democracy*Sanction } & $-0.115 * *$ & -0.0719 & -0.0389 & 0.0430 & $-0.194 * *$ & $-0.201 * *$ \\
\hline & $(0.0429)$ & $(0.0428)$ & $(0.0472)$ & $(0.0514)$ & $(0.0633)$ & $(0.0665)$ \\
\hline \multirow[t]{2}{*}{ Tradeshare*Sanction } & -0.550 & 0.528 & -0.372 & 0.367 & -0.681 & 0.705 \\
\hline & $(0.552)$ & $(0.587)$ & $(0.545)$ & $(0.600)$ & $(0.627)$ & $(0.690)$ \\
\hline \multirow[t]{2}{*}{ DefenseUS*Tradeshare } & -0.971 & 0.594 & -0.905 & 0.678 & -0.999 & 0.552 \\
\hline & $(0.769)$ & $(0.535)$ & $(0.762)$ & $(0.620)$ & $(0.851)$ & $(0.565)$ \\
\hline \multirow[t]{2}{*}{ DefenseUS*Sanction*Tradeshare } & 0.970 & -0.403 & 1.367 & -1.414 & 0.505 & 0.303 \\
\hline & $(1.050)$ & $(1.286)$ & (1.019) & $(1.654)$ & $(1.169)$ & $(1.148)$ \\
\hline \multirow[t]{2}{*}{ MID*Sanction } & -0.00719 & 0.00339 & -0.168 & -0.0369 & 0.158 & 0.0450 \\
\hline & $(0.110)$ & $(0.0570)$ & $(0.127)$ & $(0.0569)$ & $(0.115)$ & $(0.0576)$ \\
\hline Observations & 245,726 & 143,778 & 237,628 & 139,394 & 234,295 & 138,222 \\
\hline Dyads & 8,299 & 10,149 & 7,893 & 9,782 & 7,702 & 9,695 \\
\hline
\end{tabular}

Table A6 Fixed effects Poisson models of target-third-state dyadic trade, including yearly time dummies

${ }^{* *} \mathrm{p}<0.01,{ }^{*} \mathrm{p}<0.05$. Estimated coefficients with robust standard errors clustered by dyad in parentheses. Controls for real GDP, population size, and yearly time dummies included but not reported. 


\begin{tabular}{|c|c|c|c|c|c|c|}
\hline & \multicolumn{2}{|c|}{ Total bilateral trade } & \multicolumn{2}{|c|}{$\begin{array}{c}3^{\text {rd }} \text { state imports } \\
\text { from target }\end{array}$} & \multicolumn{2}{|c|}{$\begin{array}{c}3^{\text {rd }} \text { state exports } \\
\text { to target }\end{array}$} \\
\hline & 1950-1991 & $1992-2006$ & 1950-1991 & $1992-2006$ & 1950-1991 & $1992-2006$ \\
\hline \multirow[t]{2}{*}{ MID } & -0.0375 & 0.0503 & 0.0420 & 0.0672 & -0.127 & 0.0299 \\
\hline & $(0.0588)$ & $(0.0349)$ & $(0.0732)$ & $(0.0427)$ & $(0.0656)$ & $(0.0276)$ \\
\hline \multirow[t]{2}{*}{ Sanction } & $0.217^{*}$ & $-0.252 * *$ & 0.212 & $-0.419 * *$ & 0.215 & -0.0890 \\
\hline & $(0.100)$ & $(0.0779)$ & $(0.126)$ & $(0.108)$ & $(0.123)$ & (0.0919) \\
\hline \multirow[t]{2}{*}{ Defense } & $0.463 * *$ & 0.139 & $0.512 * *$ & 0.107 & $0.427 * *$ & $0.194 * *$ \\
\hline & $(0.108)$ & $(0.0727)$ & $(0.0917)$ & $(0.105)$ & $(0.149)$ & $(0.0727)$ \\
\hline \multirow[t]{2}{*}{ DefenseUS } & $0.332 *$ & $0.228^{*}$ & $0.404 *$ & $0.242 *$ & 0.210 & 0.164 \\
\hline & $(0.138)$ & $(0.104)$ & $(0.158)$ & $(0.120)$ & $(0.137)$ & $(0.121)$ \\
\hline \multirow[t]{2}{*}{ Tradeshare3T } & $3.722 * *$ & $3.423^{*}$ & $3.384 * *$ & 3.506 & $4.006 * *$ & $3.424 * *$ \\
\hline & $(0.619)$ & (1.339) & $(0.800)$ & $(1.815)$ & $(0.662)$ & $(1.085)$ \\
\hline \multirow[t]{2}{*}{ PowerUS } & $-0.647 * *$ & -0.0514 & $-0.590 * *$ & 0.0382 & $-0.704 * *$ & -0.136 \\
\hline & $(0.0850)$ & $(0.106)$ & $(0.0915)$ & $(0.124)$ & $(0.0965)$ & (0.109) \\
\hline \multirow[t]{2}{*}{ Democracy } & -0.0258 & $-0.104 * *$ & -0.0550 & $-0.126 * *$ & 0.00230 & -0.0762 \\
\hline & $(0.0471)$ & $(0.0402)$ & $(0.0556)$ & $(0.0373)$ & $(0.0538)$ & $(0.0629)$ \\
\hline \multirow{2}{*}{ Defense*Sanction } & $-0.174^{*}$ & 0.103 & $-0.237 * *$ & 0.234 & -0.112 & -0.0620 \\
\hline & $(0.0770)$ & $(0.0841)$ & $(0.0819)$ & $(0.144)$ & $(0.0958)$ & $(0.0703)$ \\
\hline \multirow[t]{2}{*}{ DefenseUS*Sanction } & $-0.136^{*}$ & 0.128 & -0.164 & 0.0859 & -0.0980 & $0.251 * *$ \\
\hline & $(0.0672)$ & $(0.0664)$ & $(0.0839)$ & $(0.0842)$ & $(0.0819)$ & $(0.0720)$ \\
\hline \multirow[t]{2}{*}{ PowerUS*Sanction } & -0.0119 & 0.0283 & -0.0272 & 0.0344 & 0.00231 & 0.0201 \\
\hline & $(0.0229)$ & $(0.0203)$ & $(0.0293)$ & $(0.0267)$ & $(0.0285)$ & $(0.0245)$ \\
\hline \multirow[t]{2}{*}{ Democracy*Sanction } & $-0.194 * *$ & $-0.146^{*}$ & -0.0958 & -0.00322 & $-0.290 * *$ & $-0.313 * *$ \\
\hline & $(0.0569)$ & $(0.0600)$ & $(0.0540)$ & $(0.0734)$ & $(0.0809)$ & $(0.0693)$ \\
\hline \multirow[t]{2}{*}{ Tradeshare*Sanction } & 0.164 & 0.812 & 0.0931 & 0.609 & 0.273 & 1.093 \\
\hline & $(1.029)$ & $(1.412)$ & $(1.093)$ & $(1.626)$ & $(1.102)$ & $(1.349)$ \\
\hline \multirow[t]{2}{*}{ DefenseUS*Tradeshare } & -0.211 & 1.449 & -0.139 & 1.467 & -0.195 & 1.392 \\
\hline & $(0.980)$ & $(1.136)$ & $(1.069)$ & $(1.465)$ & (1.014) & $(1.002)$ \\
\hline \multirow[t]{2}{*}{ DefenseUS*Sanction*Tradeshare } & 0.244 & -0.554 & 0.863 & -1.777 & -0.461 & 0.319 \\
\hline & $(1.439)$ & $(1.669)$ & $(1.404)$ & $(1.973)$ & $(1.615)$ & $(1.552)$ \\
\hline \multirow[t]{2}{*}{ MID*Sanction } & -0.0472 & -0.0438 & -0.222 & -0.0889 & 0.136 & -0.00191 \\
\hline & $(0.0966)$ & $(0.0481)$ & $(0.119)$ & $(0.0490)$ & $(0.111)$ & $(0.0474)$ \\
\hline \multirow[t]{2}{*}{ Constant } & $-11.80 * *$ & $-15.63 * *$ & $-14.79 * *$ & $-15.59 * *$ & $-9.921 * *$ & $-18.19 * *$ \\
\hline & $(1.763)$ & $(2.523)$ & $(2.020)$ & $(2.353)$ & $(2.128)$ & $(2.896)$ \\
\hline Observations & 236,962 & 147,242 & 237,405 & 147,252 & 237,374 & 147,259 \\
\hline Dyads & 8,417 & 10,767 & 8,421 & 10,767 & 8,420 & 10,767 \\
\hline
\end{tabular}

Table A7 Random effects Poisson models of target-third-state dyadic trade

$* * p<0.01, * p<0.05$. Estimated coefficients with robust standard errors clustered by dyad in parentheses. Controls for real GDP, population size, distance, contiguity, common language, colony, and whether both dyad members are either islands or landlocked are included but not reported. 